\title{
DIE QUELLEN \\ DER ENGLISCHEN SCHWANKBÜCHER DES 16. JAHRHUNDERTS.
}

I.

Die „Mery Tales, Wittie Questions and

Quicke Answeres“.

Das 16. jahrhundert ist die zeit, wo in den hauptländern Europas der kurze prosaschwank seine höchste blüte erreichte. Ausgegangen von Italien, das selber vielfach aus dem schatze der fableaux und der predigtmärlein schöpft, verbreitete er sich unter dem fortdauernden einflufs dieser beiden faktoren und unterstützt durch humanisten- nnd volksdichtung in Deutschland, Frankreich, Spanien und England, oft in engen beziehungen zur dramatischen dichtung und der verserzählung dieser länder, bald zur novelle anschwellend, bald zur scharf pointierten anekdote sich verkürzend. In dieser flut von schwankdichtungen herrscht ein unaufhörliches, geradezu verwirrendes hinüber- und herüberwogen von land zu land, so dafs es oft recht schwer wird, zu sagen, ob ein land mehr gibt oder melır empfängt. Es ist daher wohl recht anziehend, aber meist nicht leicht, die quellen mit sicherheit zu ermitteln, aus welchen der eine oder andere schwank oder gar grofse sammlungen mit hunderten vou schwänken geflossen sind. In Deutschland ist für die einheimischen schwänke des 16. jahrhunderts viel geschehen. Wir besitzen in den veröffentlichungen des Stuttgarter literarischen vereins mustergiltige ausgaben, die von sachkundigen händen mit reichen nachweisen versehen worden sind. Die italienischen, französischen,

Anglia. N. F. XIX. 
spanischen und englischen schwänke des 16. jahrhunderts sind, sei es, dals es sich um die anspruchsvolleren prosa-novellen, oder - worauf es mir hier hauptsächlich ankommt - um die s. g. fazetien handelt, wenigstens zum teil durch moderne ausgaben zugänglich gemacht worden; aber für die ermittlung ihrer quellen ist in den betreffenden ländern noch nicht viel geschehen. Am meisten hat man auch für sie noch in Deutschland getan.

In England hat der kurze prosaschwank nicht eine so hohe gunst wie z. b. in Deutschland gefunden, aber dennoch gibt es mehrere sammlungen, die berufen waren, eine nicht unwichtige rolle in ihrer heimat zu spielen. Nachdem die eine oder andere bereits in selten gewordenen liebliaberausgaben neu gedruckt worden waren, veröffentlichte W. C. Hazlitt 1864 drei bände unter dem titel Shakespeare Jest-Books. Leider lä Sst sein neudruck, so verdienstvoll er auch im ganzen für die kenntnis der engliṣchen schwankdichtung war, in mancher beziehung und am meisten betreffs der quellennachweise $\mathrm{zu}$ wünschen übrig. Ich beabsichtige daher, diesem letzteren mangel einigermalsen abzuhelfen und der reihe nach die einzelnen schwanksammlungen, die den inhalt der drei bände der Shakespeare Jest-Books bilden, auf ihre quellen zu untersuchen.

Nachdem für die erste und berühmteste unter ihnen für die durch Shakespeare's erwähnung in Much ado about nothing zur unsterblichkeit gelangten $A$ Hundred Mery Tales bereits durch Oesterley in seiner zwei jahre nach Hazlitt's neudruck veröffentlichten guten ausgabe zahlreiche quellennachweise bezw. parallelen geliefert worden sind, hebe ich mit der zweiten sammlung des I. bandes, mit den

\section{Mery Tales, Wittie Questions and Quicke Answeres}

an. Ich bemerke gleich, dals es mir in der folgenden untersuchung nicht darauf ankam, für jede nummer des schwankbuches eine recht stattliche anzahl von mehr oder weniger verwandten parallelen zusammenzustellen, wie das Oesterley, Bolte und andere in verdienstvoller weise getan haben, sondern nur, soweit es möglich war, die direkten vorlagen des erzählers zu ermitteln. Jenes verfahren würde bei den in den meisten fällen notwendigen quellenuntersuchungen störend 
gewirkt haben und meine abhandlung weit über den rahmen eines zeitschriftbeitrags hinaus anschwellen haben lassen.

Bevor ich an die eigentliche arbeit herantrete, lasse ich noch ein paar bemerkungen vorangehen.

Das was die englischen schwankdichtungen des 16. (und auch des 17.) jahrhunderts von den der übrigen länder Europas unterscheidet, das ist der umstand, dals sie durchweg von unbekannten verfassern herrühren; denn auch jene, die den namen eines berühmten dichters oder komikers führen, wie z. b. die Mery Tales of Skelton, die Jests of Scogin, die Merrie Conceited Jests of $H$. Peele usw., haben nicht diese männer, sondern, wie Hazlitt (Shakespeare Jest-Books bd. II Introductory Notice p. VII) richtig bemerkt, andere zum verfasser, die sich einen berühmten namen zu nutzen machten, um ihre erzeugnisse mit mehr erfolg auf den markt zu bringen. Diese wahrnehmung scheint geeignet, den literarischen wert der englischen fazetiendichtung herabzudrücken, und in der tat können sie einen vergleich mit ähnlichen italienischen, französischen und deutschen schwänken der gleichen zeit nicht aushalten; allein ihre wirkung auf die zeitgenossen und ihr einflufs auf damalige und spätere dichter ist deshalb nicht geringer gewesen, beschränkte sich jedoch nur auf England.

Das fehlen eines verfassernamens bei den Mery Tales, Wittie Questions and Quicke answeres soll uns indes nicht gegen sie von vornherein beeinflussen. IVir werden weiter unten sehen, dals der unbekannte verfasser, wenn er auch keinen anspruch auf originalität erheben kann, doch ein nicht übler erzähler ist.

Er war jedenfalls nicht mit dem der weit originelleren und älteren $A C$ Mery Talys identisch. Die jüngere sammlung verrät einen des Lateinischen kundigen, in der antiken literatur belesenen und in zitaten daraus sich gefallenden schreiber. Auch der verfasser von $A C$ Mery Talys verstand Latein, gehörte also gleich dem kompilator der Mery Tales, Wittie Questions and Quicke Answeres zur zunft der gelehrten, aber während dieser den Griechen und Römern zahlreiche schwänke entlehnte, entnahm jener der alten literatur weder zitate noch stoffe. Bei genauem vergleich $\mathrm{zwischen}$ den beiden erzählern wird man auch unterschiede im stile zwischen ihnen finden. 
Jedenfalls diente dem jüngeren sammler die ältere als vorbild. Das ersieht man aus der form der darstellung, der grölse der gewählten schwänke, aus der art der überschriften, aus den angefügten moralischen lehren und nutzanwendungen usw.

Um so merkwürdiger, dals er - was man von späteren ähnlichen sammlungen leider nicht sagen kann - aus seinem vorbild nicht eine einzige geschichte in seine kompilation aufgenommen hat. Er hatte offenbar den ehrgeiz, nur neues zu bringen. Treten wir nun der frage näher, woher er seine stoffe genommen hat.

Wie bereits erwähnt, hat Hazlitt nur über die quellen von ein paar stücken andeutungen gemacht. In weuerer zeit haben sich E. Köppel und F. Brie gelegentlich ganz kurz über die quellen unseres schwankbuches geäufsert.

Der erstere (Studien zur Geschichte der ital. Novelle in der englischen Literatur etc. s. 78), die drei sammlungen Mery T'ales, Wittie Questions etc., A Hundred Mery Talys und die Pasquil Jests zusammenfassend, findet, dals in ihnen „der italienische einflufs besonders zur geltung kommt". "Hier finden wir", sagt er, „in kondensierter form manche bekannte italienische novelle, ... weit zahlreicher sind jedoch die entlehnungen aus Poggio und aus Domenichi's "Facetie, Motti e Burle"." Im einzelnen bezeichnet E. Köppel als quellen der Mery Tales (Studien s. 83 bezw. 99)

1. für nr. 51 Of the inholders wyfe and her two louers $=$ Decamerone VII, 6 ,

2. für $\mathrm{nr} .52$ Of hym that healed franticke men $=$ Straparola XIII, 1.

An diesen angaben ist nur das eine richtig, dafs Poggio sicher von den Mery Tales $W$. $Q$. und vielleicht von den $A C$ Mery Talys benützt worden ist. Domenichi's Facetie, deren erster druck vom 9. Oktober 1548 datiert ist, können nicht eine vorlage der bereits 1525 erschienenen $A C$ Mery Talys gewesen sein; sie waren es, wie sich weiter unten zeigen wird, auch nicht für die Mery Tales W. Q. Was die 1604 veröffentlichten Pasquil Jests anbelangt, so beruhen sie überhaupt, wie in der ihnen gewidmeten arbeit gezeigt werden wird, ausschliefslich auf englischen quellen, wovon die 
wichtigste gerade unser schwankbuch ist. Irrig ist es auch, das für schwank nr. 51 der Mery Tales das Decamerone und für schwank 52 Straparola die quelle war; das richtige ist weiter unten angegeben.

Es ist mir vollkommen begreiflich, wie Köppel dazu kam, die Facetie Domenichi's für eine fundstätte unseres schwankbuches zu halten. In dieser italienischen anekdotensammlung finden sich eine anzahl von schwänken, welche auffallend mit solchen bei dem englischen erzähler in der darstellung übereinstimmen, so dals die verführung, jene als die quellen der letzteren anzusehen, recht grofs war. Es durfte eben nicht übersehen werden, dals Domenichi einer der kecksten plagiatoren seiner zeit war, der seine vorlagen, zu denen auch deutsche, englische und niederländische humanisten gehörten, fast wörtlich benützte, bezw. übersetzte. Köppel hätte also prüfen müssen, ob der englische schwankdichter nicht Domenichi's eigene quellen zur vorlage hatte, oder ob es nicht ältere genauer entsprechende, oder näher liegende versionen gab.

Brie (Eulenspiegel in England s. 74 ff.) meint, dafs die A C Mery Talys, die Mery Tales und The Sack-Full of Newes "Bromyard, Poggio und Bebel ihre entstehung danken". Wie in den H. M. T. Bromyard vorherrscht, so in den T. Q. A. Poggio. Doch enthalten letztere, von denen uns wahrscheinlich auch der originaldruck von c. 1535 erhalten ist, deutliche spuren des Howlglass, so in nr. LXXXIV "Of hym that shulde haue ben hanged for his scoffynge". Des weiteren bezeichnet er als entlehnungen aus Poggio: nr. 6, 18, 36, 38, 40, 44, 57, 58,$66 ; 70,74,76,82,87,92,99,100$. Eudlich glaubt Brie die „spuren Bebels auf englischem boden besonders aus den 'T. Q. A. um ein bedeutendes vermehren" zu können.

Auch diese angaben bedürfen zum teil der berichtigung. Was die benutzung des Houlglass anbetrifft, so habe ich bereits in einer rezension des Brie'schen buches (Studien für vergl. Literaturgeschichte band VIII s. 136-140) gezeigt, dals der Engländer für nr. 84 eine andere quelle hatte. Dals Poggio eine wichtige fundstätte der Mery Tales sei, hat Brie richtig erkannt, aber von den 17 nummern, die er auf ihn zurückführt, gehen 9 , nämlich $36,38,40,44,58,66,76$, 82, 99 nicht direkt auf Poggio, sondern auf eine andere quelle 
zurück. Ganz ausgeschlossen ist es, dafs Bebel eine vorlage des Engländers bildete; für die wenigen nummern, in welchen der letztere sich dem ersteren inhaltlich näherte, also z. b. für $\mathrm{nr} .10$ "Of the yonge woman that sorowed so greatly her husbondes deth" = Bebel's Facetiae II. B. Nr. 71 (Ausg. 1514 Bl. Gg. 2a) „De quadam muliere citissime nubente post obitum primi viri"; für nr. 83 "Of the poure man, into whose house theues brake by nyghte" = Bebel I. B. nr. 71 "De Histrione"; nr. 119 "Of the fryer that praysed saint Frauncis" = Bebel II, 81 "De quodam minore" u. a.m. sind näher stehende versionen vorhanden, bezw. solche, die der Engländer auch sonst benützte, während sich bei ihm auch nicht ein einziger schwank nachweisen lälst, der nur ihm und Bebel gemeinsam wäre.

Schon vor Köppel (1892) und Brie (1903) hatte Ch. H. Herford in seinem anregenden buche Studies in the Literary Relations of England and Germany (Cambr. 1886 University Press) ein paar andeutungen über die quellen der Mery Tales gemacht, indem er s. 253 Bromyard und s. 271 für nr. 84 Marcolf und den Eulenspiegel als quellen bezeichnete. Die letzte angabe ist ein irrtum und ob Bromyard als eine quelle der Mery Tales anzusehen ist, wird sich weiter unten zeigen.

Ich schreite nun zur betrachtung der einzelnen schwänke. $\mathrm{Zu}$ einer reihe von allgemeinen bemerkungen insbesondere auch zur datierung unseres schwankbuches, wird sich am schlusse der abhandlung gelegenheit bieten.

1. Of hym that rode out of London and had his seruant folowynge on foot. (S. 15.)

Quelle: Poggio Facetiae (Londini MDCCXCVIII) Equus calcitrosus (s. 171).

Der Engländer hat ziemlich wörtlich übersetzt, nur hat er aus dem nach Tervisium reisenden "Venetus" einen bewohner Londons gemacht "that rode V myle out of London".

In der ausgabe der Opera Poggios 1513, gedruckt bei Knoblauch in Stralsburg, steht der schwank fol. $173 \mathrm{~b}$ unter der aufschrift "De Veneto qui Tervisium proficifcens a feruo in renes lapide percuffus est." 
DIE QUELLEN DER ENGL. SCHWANKBÜCHER DES 16. JAHRH. 459

2. Of hym that preched on saynt Chrystophers day. (S. 16.)

Quelle: Poggio's Facetiae (Londini MDCCXCVIII) Asinus D. Christophoro Major (seite 208). Ausg. Strafsb. 1513 Bl. 177 "De predicatore quodam".

Die anekdote ist mit einigen kleinen kürzungen, aber sonst ziemlich genau nach Poggio wiedergegeben.

3. Of the frenche man, that stroue with the Janway for his armes. (S. 16.)

Quelle: Poggio's "Scutum" (Lond. 1798 s. 120) Ausg. $1513 \mathrm{Bl} .177$ "De duorum contentione pro eodem infigni armorum".

Die anekdote bietet in der englischen nachahmung keine irgendwie nennenswerten abweichungen von dem lateinischen vorbild.

4. Of the curate that sayde our Lorde fedde V. C persons. (S. 17.)

Quelle: Poggio: "100 pro 1000". (Lond. 1798 seite 231) Strafsb. 1513 s. 179 "Sacerdos predicauit in numero errauit centum pro mille dicens."

Die vorlage wurde vom Engländer wörtlich übersetzt.

5. Of hym that profered his doughter in mariage (S. 18.)

Quelle: Poggio, "Probata fæcunditas" (Lond. 1798 s. 162) Str. 1513 bl. 172 b "De montano qui filiam defponfare nolebat."

Guicciardini L'Hore di Ricreatione (Ed. Ven. 1572 s. 364) hat die gleiche anekdote, wörtlich aus Poggio über'setzt, aber er kann die quelle des Engländers nicht sein, weil sein buch vor 1567 nicht gedruckt wurde.

6. Of them that came to London to bye a Crucifixe. (S. 18.)

Quelle: Poggio "Crucifixus vivus" (Lond. 1798 s. 24) Str. 1513 bl. 159 a "De rufticis nuncijs interrogatio an uellent cruxifixum viuum | an mortuum ab opifice emere." 
Auch diese anekdote ist aus Poggio nahezu wörtlich übersetzt.

Reiche nachweise zur verbreitung des scherzes hat Bolte zu seiner ausgabe von Frey's Gartengesellschaft nr. 2 (Stuttg. Liter. Verein bd. 209 s. 216 f.) gegeben. Semerau in seiner übersetzung der Fazetien Poggios hat die nachweise Bolte's nachgeschrieben ohne diesen und seine ausgabe Frey's zu erwähnen.

7. Of hym that folowed his wyfe to buryenge. (S.19.) Quelle: Abstemius, Fabulae nr.61. "De Adolescente in funere matris canente."

Die gleiche anekdote hat auch Bebel Abstemius entlehnt. Dals aber der letztere und nicht Bebel vorlage für den Engländer war, lehrt die nachfolgende zusammenstellung.

A man that wepynge folowed his wyfe to buryenge, rebuked his lyttel sonne, that wente with hym, because he sange, sayenge that he was peuysshe and madde to synge at his mothers buryenge, but he shulde rather be sory and wepe. The chylde anfwered: father, seynge ye gyue to thefe prestes money to synge at my mothers buryenge, why be ye so angry with me etc.
Abst. Vir quidam defunctam vxorem quae ad fepulchrum efferebatur, lachrymis \& fletibus profequebatur. Filius vero eius canebat, qui cum a patre increbatur vt amens \& infanus, qui in matris funere cantaret, cum vna fecum moeftus effe \& flere deberet, inquit: pater mi, fi facerdotes vt canerent conduxisti, cur mihi irafceris gratis concinenti?
Bebel I, 17.

Dicitur mihi de alio ftupido homine \& fatuo qui cum funus maternum profequeretur, cantabat alta voce, quem cam pater caltigaret, dixit: Haud effe te fanum credo pater etc.

Auch Camerarius Fabulae Aesopicae, aber erst in späteren ausgaben, so z. b. in der Lpz. 1576 erchienenen, hat die geschichte (s. 77 "Adolefcens cantans in funere Matris.").

8. Of hym that felle into the fyre. (S. 19.) (Trunkenbold der sein weib schlecht behandelt, fällt taumelnd ins feuer am kamin. Die davon benachrichtigte frau sagt, man solle ihn doch in seinem eigenen haus sein vergnügen suchen lassen, wo es ihm beliebe.)

Quelle: Bromyard Summa praedicantium H. Cap. I, 16 (Ausg. Ven. 1586, 40, bd. I, bl. 350 a).

Die lateinische erzählung ist sinnreicher, vollständiger. Bei Bromyard hatte die frau ihrem manne vorwürfe wegen 
seines trinkens gemacht; doch er "offensus ipsam rogauit cum minis, quo illum in domo fuo fuae dimitteret voluntate" und die frau erschreckt, "promilit le uelle pactum tenere". Das alles fehlt bei dem schwanksammler. Dagegen fülırt er aus, dals eines abends die frau $\mathrm{zu}$ bette gegangen war und ihrer magd befohlen hatte, ein feuer zu machen und auf zu bleiben bis der trunkenbold käme; "about XII of the clocke home he came and as he stode warmynge him by the fyre his hede was so tottye that he felle into the fyre". Bei Bromyard heirst es an stelle von allem diesem: "Accidit ... quod femel ebrius in ignem caderet." Von da ab gehen beide versionen mehr zusammen; man vergleiche:

$$
\text { Mery Tales. }
$$

The mayde seing him fall, ranne vp cryenge to her maistress and sayd: Alas, my maister is fallen ... in the fyre. No force, mayde, said her maistres, let him lye and take his pleasure in his owne house, where so euer him listeth.

\section{Bromyard.}

... de quo cum famuli currentes eum extrahere uellent, reftitit uxor dicens, permittatis eum in domo fua uoluntatem fuam habere \& iacere vbicumque ei placet.

Bei Bromyard fügt die frau noch die gründe für ílhre handlungsweise hinzu, während der jüngere erzähler mit obigen worten schliefst.

\section{Of him that vsed to cal his servant the kinge of foles. (S. 20.)} Seruo."

Quelle: Abstemius. nr. 30 "De Diuite quodam et

Die abhängigkeit lärst sich durch wörtliche übereinstimmungen beweisen:

There was a man that had a dulle lumpisshe felow to his seruant, wherfore he vsed commonly to call him the kinge of fooles. The felow at laste waxed angry in his minde to be always so called and sayde to his mayster: I wolde that I were the king of foles etc.
Vir erat diues, feruum habens tardi ingenii, quem regem ftultorum folebat nuncupare. Ille his verbis faepins irritatus, statuit hero par referre. Semel, enim in herum conuerfus: Vtinam, inquit, rex stultorum effem etc.

Die anekdote findet sich in ital. sammlungen, so z. b. in Guicciardini's Hore di Ricreatione (Ausg. Ven. 1572 s. 46), die 
aber als quelle schon aus chronologischen gründen nicht in betracht kommen können.

10. Of the yong woman that sorowed so greatly her husbondes deth. (S. 21.) [Fragt, als die beerdigung vorbei ist, nach dem jungen mann, den ihr vater ihr bestimmt.]

Quelle: Abstemius nr. 14. "De Muliere uirum morientem flente \& Patre eam confolante." Auch diese fabel hat Guicciardini übernommen (s. 322).

Eine ähnliche anekdote hat auch Bebel II nr. 71 (Opuscula $1514 \mathrm{Gg}$ 2): "De quodam muliere citissime nubente", die vielleicht auf Abstemius zurïckgeht, aber dem Engländer ferner steht. Über die verbreitung beider versionen vgl. Oesterley zu Kirchhof 1,346, der aber noch der ergänzung sehr bedürftig ist. So ist $z$. b. vergessen Guicciardini Hore di Ricreatione (Ven. 1572) s. 322.

\section{Of him that kissed the mayd with the longe nose. (S. 21.)}

Quelle: Thomas Morus Epigramm: De Tyndaro. Ich stelle vorlage und nachbildung hier zusammen:

A bablynge gentylman, the whiche on a tyme wolde haue bassed a fayre mayd, that had nat the leest nofe, sayde: how shulde I kysse you: your nofe will not suffre our lyppes to mete. The mayden, waxinge shamfast and angrye in her mynde (for with his scoffe he a lyttell touched her) answered on this wyse: syr, if ye can not kysse my mouth for my nofe, ye may kysse me there as I haue nere a nose.
Non minimo infignem naso dum forte puellam Bafiat, en uoluit Tyndarus effe dicax.

Fruftra, ait, ergo tuis mea profero labra labellis

Noftra procul nafus diftinet ora tuus.

Protinus erubuit, tacitaque incanduit ira,

Nempe parum falfo tacta puella fale,

Nafus ab ore meus tua fi tenet ofcula, dixit,

Qua nafus non eft, hac dare parte potes.

Die erzählung findet sich auch bei Domenichi Facetie Motti e Burle s. 128 (Ausgabe Ven. 1588, aber sie steht der englischen darstellung ferner, man vergleiche; Baciando un 
giouane, una fanciulla, che hauea il nafo longo, per parer faceto \& acuto nel parlare, difle: fanciulla mia, Io ti porgo in uano i labri per baciarti; perche il tuo nafo longo non me gli lafcia accoftare alla bocca. La fanciulla diuentò roßa \& s'infiammò tutta nella colera e parendole eßere ftata uillanamente morfa, diffe, poi che il mio nafo non lafcia accoftare la tua bocca alla mia, baciami donque da quella parte, doue io non ho nafo.

12. The Uplandishe mans answere, concerninge the steple and pulpit. (S. 23.) [Weil die ortskirche keine glocken hat, so rät der bischof den kirchturm zu verkaufen, ein bürger antwortet ihm, besser wäre es die kanzel zu verkaufen, da sei seit sieben jahren nicht gepredigt worden.]

Quelle: Ein lateinisches predigtmärlein?

13. Of the beggers answere to Mr. Skelton the poete. (S. 23.) [Der dichter wünscht ihn zur hölle; die sei nicht für arme leute, meint jener, sondern für so feine wie er.]

Quelle: Mündlich?

14. Of the chaplen, that sayde our ladye matens a bed. (S. 24) ["where shudde women be serued but a bedde?"].

Die quelle dieses zynischen oder richtiger gesagt, gemeinen witzes, darf vielleicht in einem mittelalterlichen exempelbuch gesucht werden, die mitunter von unglaublicher naivität und unverfrorenheit sind.

15. Of him that lost his purse in London. (S. 25.) [Landmann wird vom edelmann, bei dem er seine börse wiederzufinden hoffte, verhöhnt: „ich werde dir nie mein geld aufzubewahren geben etc."]

Dieser in London spielende schwank hat vielleicht eine englische quelle.

16. Of the marchaunt that lost his bodgette betwene Ware and London. (S. 26.)

Quelle: Am nächsten kommt unserer darstellung dieser weitverbreiteten erzählung, über die Oesterley zu Pauli's 
Schimpf und Ernst nr. 115 sehr viele parallelen zusammengetragen hat, der erste teil einer alten englischen ballade, welche sich in der schönen sammlung Bishop Percy's Folio Mamuscript Ballads \& Romances ed. by J. W. Hales and F. J. Furnivall (London, Trübner \& Co. 1868) bd. III s. 127 ff. befindet unter dem titel "Marke More Foole".

Während der verlierende - meist ein kaufmann - in anderen versionen 800 gulden (Pauli) oder 400 scudi (Giraldi) oder 1000 goldstücke und eine goldene schlange (Disciplina clericalis und Libro de los enxemplos) verliert, sind es bei beiden englischen versionen übereinstimmend „a 100 li“. Bei beiden verspricht der kaufmann dem redlichen finder eine belohnung von „20 li“, bei Pauli dagegen 100 gulden, ebenso in der Disciplina clevicalis und im Libro de los enxemplos, bei Giraldi 40 scudi, bei Sercambi und Timoneda (Patraña 6) 10 goldstücke etc. Die beziehungen $\mathrm{zwischen}$ den beiden englischen versionen erstrecken sich noch auf ein paar wörtliche übereinstimmungen; man vergleiche:

\section{Mery Tales.}

A certayne merchant ... lost his bodget and a $\mathrm{C}$ li therin, werfore he caused to proclayme ... that who so euer found the sayd bodget and wolde bryng it agayne shulde haue XX li for his labour.

An honeste husbandman that chaunsed so fynde the sayde bodget.
Marke More Foole.

. . . . . a riche Merchant as he rode to a markett towne itt was his chance to lose his purse he said there was in itt a 10011

a proclamation he caused to be made whosoener cold find the same againe shold give itt him againe . . . .

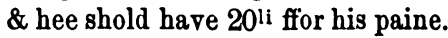

"the poore man" sagt hier vor dem richter:

"itt was my chance to ffind that pursse."

Endlich behauptet in beiden englischen versionen der kaufmann, dal's er 120 li verloren habe und dals der finder, nachdem er nur 100 abgeliefert, die 20 li finderlohn sich schon angeeignet habe.

Hier endigt aber die übereinstimmung. In den Mery Tales verlangt der "husbandman" den versprochenen lohn und da er ilın vom kaufmann nicht erhält, so gehen sie zusammen zum "good Judge" Vavasour, in begleitung des "baily of Ware", bei dem jener den "bodget" deponiert hatte. Der 
richter entscheidet, dafs der finder das geld behalten solle; wenn er aber einen "bodget" mit 120 li fände, so habe er ihn dem kaufmann auszuhändigen.

Anders das gedicht. Darin kommt die sache vor könig Salomon und sein "foole" Marke More erbietet sich den fall sowie zwei andere - der finder hat, vor dem kaufmann die flucht ergreifend, einer Ladye ein auge ausgestofsen und ins meer sich stürzend einen fischer getötet - zu entscheiden. Durch verknüpfung der drei fabeln mufste die lösung hier eine andere sein. Das gedicht gehört in den kreis des bekannten dem Orient entstammenden und in zahlreichen versionen verbreiteten märchens, über das Th. Benfey (in der vorrede zu seiner Pantschatantra-Übersetzung I, $394 \mathrm{ff}$.) und Reinhold Köhler (Kl. Schriften II, 578 f.) gehandelt haben und nähert sich noch am meisten Sercambi.

Es fragt sich nun, hat der verfasser des schwankbuches das gedicht gekannt und benutzt? Die herausgeber des letzteren meinen, dafs es unter den "Tudors or the first Stuarts" entstanden sei. Das ist nicht richtig; ich vermute vielmehr, dals es dem 15. jahrliundert angehört; den Marke More Foole ist sichtlich - was den herausgebern entgangen ist - eine entstellung aus Markolf the Foole, ein name, den man im 16. jahrhundert, wie es scheint, nicht mehr verstand. Das gedicht ist also jedenfalls älter als das Jestbook. Aber wenn es dem verfasser des letzteren bekannt gewesen wäre, hätte er es dann nicht ganz in seiner sammlung verwertet, anstatt sich mit einem, dem ersten der drei abenteuer zu begnügen? Hierauf lä Sst sich antworten, dals das ganze gedicht 200 verse oder fünf grofse seiten umfalst, während die schwänke der Mery Tules mit wenigen ausnahmen nur ein bis drei dutzend zeilen lang sind; selbst die längsten erreichen noch nicht drei seiten zu je 25 zeilen. Mehr von belang ist der einwand, dals die zweite hälfte des schwanks so ganz und gar von der behandlung im gedicht abweicht. Nachdem jedoch der kompilator auch sonst ein paar male zwei verschiedene versionen verschmolzen hat, so liegt, angesichts der oben angeführten auffallenden übereinstimmungen, die vermutung nahe, dals er das erste abenteuer von Marke More Foole mit irgend einer landläufigen version der anekdote - in der lösung sind ja fast alle gleich - kontaminiert hat. 


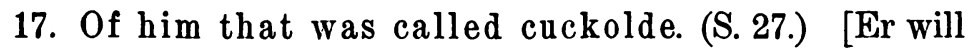
seine frau zwingen $\mathrm{zu}$ schwören, dafs er es nicht sei; sie schwört auch; aber - das gegenteil.]

Quelle: Mündlich?

18. Of the iolous man. (S. 28.)

Quelle: Poggio's "Annulus" (L., seite 141; StraIsb. 1513 blatt 170 b "Vifio Francifci Philelphi"). Poggio erzählte die schmutzige anekdote, die er wahrscheinlich einem alten französischen schwank entlehnte, boshafterweise von dem bekannten humanisten Franciscus Philelphus, mit dem er auf feindseligen fufse lebte und den er bei jeder gelegenheit mit giftigen unflätigkeiten überschüttete, was ihm übrigens Philelphus reichlich heimzahlte. Der englische schwanksammler hat begreiflicherweise den namen weggelassen und die unsaubere schnurre stark verkürzt.

Anderen versionen, wie z. b. den Cent nouuelles nouuelles 11, steht der Engländer ferner.

\section{Of the fatte woman that solde frute. (S. 28.)}

Quelle: Erasmus Coloquia famil. (Opera, Bas. 1540 I, s. 644), vielleicht nicht direkt, sondern aus Gast, Convivales Sermones I, 303 De alio quodam entnommen; letzterer hat die erzählung wörtlich übernommen und der Engländer hat mit ein paar kleinen weglassungen wörtlich übersetzt. Hier eine stelle:

Syr, wyll ye haue any fygges; they be fayre and good? And whan she sawe he was content, she sayde, how many? will ye have fyue li?
Vis, ait ficos? Sunt perquam elegantes. Quum ille annuiffet, rogat quot libras vellet. Vis, inquit, quinque libras? ${ }^{1}$ )

1) Die gleiche anekdote - die wie alle erzählungen aus dem Convivium fabulosum sehr verbreitet ist - enthält auch (nach Gast) das schwankbuch Domenichi's (Ausg. 1588 s. 57) und zwar im wortlaut sich der lateinischen fassung eng anschliefsend, so dafs es wirklich schwer ist zu sagen, ob der Engländer es oder Erasmus-Gast benützte. Folgende zusammenstellungen entscheiden meines erachtens die frage:

\section{Mery Tales.}

W'han she tourned to have taken her money and sawe her chapman go his waye, she
Erasmus-Gast.

Vbi prodiffet acceptura pecuniam, uidit emptorem abire. Infequitur maiore noce,
Domenichi.

La donna fendo ufcita fuol di bottega per pigliare i de nari, uide il compratore, ch 
20. Of a poller that begyled a prest. (S. 29.)

Quelle: Erasmus Colloquia famil. (Opera Bas. 1540 I, s. 645).

Auch hier mochte der nachahmer Gasts Convivales Sermones benutzen, woselbst die erzählung kurz vor der obigen, s. 299, unter der aufschrift De Sacrifico quodam zu finden ist, und wiederum wörtlich. Die übersetzung des Engländers folgt treu der vorlage und sogar das lokal Antwerpen (Andwarpe) ist beibehalten.

\section{Of Papirius pretextatus. (S. 31.)}

Als quelle bezeichnet der verfasser selber in den anfangsworten Aulus Gellius, und es ist denkbar, dafs er dessen Noctes Atticae I, 23, worin die anekdote erzählt wird, vor sich gehabt hat. Möglich ist es indes auch, dafs er die ungeheuer verbreitete geschichte in einer Fazetiensammlung las. So stimmt z. b. die darstellung bei Gast Convivales Sermones I, 214 "De Papyrio historia" wörtlich mit der des Gellius überein. Da aber bei Gast die quellenangabe (Gellius) fehlt, so kann er kaum die vorlage des Engländers gewesen sein.

22. Of the corrupte man of lawe. (S. 33.) [Bestechlicher richter; schwein stö[st ölflasche um.]

Quelle: Poggio, Olium effusum (L. seite 263).

Der gleiche schwank findet sich auch in den 1501 gedruckten lateinischen fabeln Seb. Brants (Efopi appologi fiue mythologi cum quibuldam carminum et fabularum additionibus Sebastian Brant) (Basel fol. 1501) auf blatt A 5 b unter der aufschrift "Quod corruptus iudex male pronunciat". Brant hat eine einleitung und am schlufs eine moral hinzu-

made after apace, but faster with her voice than with hir fote. He, dissemblinge the mater, wente styll forth on. She made suche a cryenge and folkes gathered so faste, that he stode styll. So in the preace he shewed to the people all the matter etc. quam curfu. Ille dißimulans pergit, quò coepit ire. Tandem nultis ad fominae uocem concurrentibus reftitit. Ibi in populi corona agitur caufa. s'andaua con Dio: onde gridando cominicò a leguitalo. Et egli fingendo pure che ella non diceffe a lui feguitaua il suo viaggio. Pure concorrendo molti alla noce della donna, fi fermò quiui fatto un cerchio di molti, \& fi cominciò a trattare della caufa. 
gefügt, sonst aber Poggio's text getreu wiederholt. Ich glaube, dals der Engländer indes ihn und nicht den Italiener benützt hat, weil er mit Brant in der aufschrift ähnlichkeit zeigt. Letztere lautet in den alten ausgaben Poggio's: De arbitro in cuins domo porcus oleum effudit. Nachweise: Oesterley zu Pauli nr. 128, Bolte zu Montanus Gartengesellsch. nr. 63.

23. Of Kynge Lowes of France, and the husbandman. [Conon.] (S. 34.)

Quelle: Erasmus Colloquia fam. (Opera, Basel 1540, bd. I s. 645 .)

Wiederum findet sich die erzählung bei Gast Conv. Serm. (I, 169). Auch hier ist die benutzung bei Gast und dem engl. Schwankbuch eine ähnliche wie oben. Es ist die bekannte ungemein verbreitete erzählung von der geschenkten und königlich bezahlten rübe. ${ }^{1}$ ) - Ein paar nachweise lieferte Oesterley zu Kirchhoffs Wendunmuth 2, 39.

1) Auch diese bekannte erzählung findet sich in Domenichi's Facetie (Ven. 1588 s. 142) fast wörtlich aus Gast übersetzt. Dals der Italiener aber für die englische erzählung nicht vorlage war, beweisen die nachstehenden stellen:

Mery Tales.

What tyme kynge Lowes of Fraunce, the XI of that name, bycaufe of the trouble that was in the realme kept hym selfe in Burgoyne, he chaunced by occasion of hauntinge to come acqueynted with one Conon a homely husbandman and a plaine meanynge felowe, in whiche maner of men the hygh princes greatly dely te them ... Conon peaked into the courte ... the king toke it more gladly and bad one that was nerest to him... he commaunded to gyue hym a thousande crownes of gold for his radisshe rote.

featly folded vp in sylke.
Erasmus-Gast.

Ludouicus Galliarum rex eius nominis undecimus, quum rebus domi turbatis, peregrinaretur apud Burgundiones, occasione uenationis, nactus est familiaritatem cum Conone quodam homine ruftico, fed animi fimplicis ac fynceri. Nam hoc genus hominibus delectantur monarchae ... Vbi Conon prorepfiffet in aulam .. rex maiore cum alacritate accepit, mandans cuidam e proximis ... iuflit pro rapa numerare mille coronatos aureos.

feric 0 diligenter obuolutum.
Domenichi.

Ludouico undecimo, Re d Francia trouandofi in Bor gogna al tempo dell guerra del ben publico fece fu la caccia famigliarit con un certo Conone, il qual era contadino, ma però per fona d'animo femplice fchietto, Percioche $i$ princip grandi fogliono dilettars molto de gli huomini di queft forte ... Giunto che fu Co none in corte ... il $\mathrm{Re}$ an ch'egli lietamente il riceuett ordiuando a uno dei feruitori che egli haueua appreffo .. gli fece contare mille scud d'oro.

diligentemente riuolto in $\mathrm{u}$ drappo. 
24. Of an other picke-thanke, and the same kynge. (S. 37.) [Diener findet auf dem könig eine laus und wird belohnt, ein anderer einen floh und wird gezüchtigt.]

Quelle: Erasmus Colloquia (Opera Basel 1540 s. 646).

Gast Conv. Serm. bringt diese geschichte (I, 170) wörtlich nach Erasmus. Der englische nacherzähler hält sich im ausdruck ziemlich genau an den lateinischen text; nur änderte er einen kleinen umstand, der erste diener erhielt bei ihm "fifty crownes", der zweite "fifty strypes", dagegen bei Erasmus und Gast "coronatos quadraginta" bezw. "quadraginta plagas". 1)

25. Of Thales, the astronomer that fell in a ditch. (S. 38.) [Die bekannte vielverbreitete anekdote, über die ich kürzlich im Archiv f. d. St. d. n. Spr. bd. 119, s. 189-192 gehandelt habe.]

Bei der ungeheuren verbreitung der anekdote und der grofsen übereinstimmung der versionen unter einander ist es natürlich schwer zu sagen, welche vorlage der Engländer gehabt hat. $\mathrm{Er}$ beginnt: "Laertius wryteth"; allein dals dieser nicht die quelle bezw. nicht die einzige quelle gewesen, beweist eine vergleichung des wortlauts bei beiden. So sagt z. b. der Engländer: "O Thales ... thou ... knowest nat

1) Domenichi, der (Facetie 1588, s. 31) diese geschichte gleichfalis Erasmus-Gast entnommen, kann nicht die quelle des Engländers gewesen sein, so sehr er ihm, bezw. Beiner vorlage nahe kommt; das wird durch eine genaue vergleichung der drei versionen bestätigt:

Mery Tales.

Oh! quod the kynge, it is ood lucke: for this delareth me to be a man. or that kynde of verเyneprincipally greueth iankynde, specially in outh.

And whan the kynge contrayned him to tell what it was, with moche disemblyng shamfastnes he ıyd, hit was a flee.
Erasmus-Gast.

Letum, inquit (rex) omen est. Declarat enim me elfe hominem, quod hoc genus uermiculorum peculiariter, infeftet hominem præfertim in adolefcentia.

Qu um urgeret rex tergiuerfantem, ut diceret quid effet, mire fimulato pudore, tandem refpondit, effe pulicem.
Domenichi.

Isiffe dunque il Re che cio era buon fegno, perche fimili animaluzzi uanno intorno a gli huomini, maffimamente nella lor giouanezza.

Perche uolendo pur fapere il Re da colui che gli haneua fatto, mostrando egli di vergognarfi a dirgliele, finalmenta rifpole che egli era una pulce. 
what is here benethe vnder thy feet", während Laertius sagt: "... o Thales ... qui ea quae funt ante oculos videre non vales". 1) Anderseits konnte Gast, welcher (I, 284) die anekdote auch bringt, nicht seine vorlage sein, weil dieser von einem "puteum" spricht, in den Thales gefallen war, während die englische version von einem "ditche" (= fossa bei Laertius) spricht. Beide versionen zusammen aber würden genügen, um den englischen text zu erklären. So sagt z. b. Gast: "O Thales ... qui quod ante pedes erat non videris." Ferner sagt er: "anicula, cuius ipfe domi utebatur minifterio deridens... inquit" und der Engländer: "an olde woman, that he kepte in his house laughed and sayde to him in derision". Laertes bietet hier nur die zwei worte "anus domeftica".

Möglicherweise hat der Engländer seine darstellung aus den beiden zusammengeschweifst, es ist aber auch nicht ausgeschlossen, dals er eine einzige mir z. z. unbekannte version benützte. ${ }^{2}$ )

26. Of the astronomer that theues robbed. (S. 39.) [Verkündigt die zukunft und weils nicht, dals er gerade bestohlen wird.]

Quelle: Seb. Brants Fabulae (Bl. E 4b) "De augure qui furtum rei fue preuidere non potuit". Brant selber

1) Der englische kompilator kannte ihn wahrscheinlich aus einer lateinischen übersetzung.

2) Die verbreitung der anekdote ist in der tat ungewöhnlich grofs. Ich nehme selten eine fazetien- oder apophthegmensammlung des 16. jahrhunderts zur hand ohne auf neue versionen zu stofsen. Hier ein paar proben, die noch nicht angeführt worden sind: Barlandus Joci (1529) Thales philosophus (bl. 7a). Diese version ist identisch mit der oben erwähnten von J. Gast. Da Barlandus dabei angibt "Ex Laertio", so wäre es verständlich, warum der Engländer, der, wie später gezeigt wird, Barlandus kannte, dazu kam zu sagen "Laertius wryteth". Der verfasser der Mery Tales mufs also nicht unbedingt den Griechen selbst benutzt haben. Le Parangon de Nouvelles Honneftes (Paris 1532) bl. 105 Dit ioyeux \& facecieux moralifé du philofophe Thales; Amoniffima et Pudica Iocorum Facetiarumque fylua (Argent. 1842) bl. 54 b "De Thalete" (ans Luscinius); Gabriel Faernus, Fabulae Centum nr. 73; auch in der Mythologia Metrica \& Moralis (Hamburgi 1698) 8. 60. - Albrecht v. Eyb, Margarita poetica bl. 267 a (Ausg. Arg. 1503, 4º). 
schöpfte den schwank aus den von Laurentius Valla aus dem Griechischen übersetzten 33 fabeln, wo er unter dem titel De vate quodam die 25. stelle einnimmt. Die gleiche fabel hat auch Rimicius unter gleichem titel.

Dals Brant, der L. Valla wörtlich folgte, die vorlage des Engländers war, wird dadurch bewiesen, dals die schlufsworte bei letzterem: "And Cicero saythe: That wyse man, that can nat profytte him selfe hath but lytell wysdome" sich nur bei Brant finden, dessen einziger zusatz sie sind: "Probe igitur, inquit Tullius, Qui fibi ipfi prodeffe nequit ne quicquam fapit etc." -

27. Of the plough man that sayde his pater noster. (S. 39.) [Denkt dabei an andre dinge.]

Quelle?

28. Of him that dreamed he fonde golde. (S. 40.) [Auf anraten des teufels kennzeichnet er den fundort und beim erwachen hat er das bett verunreinigt.]

Quelle: Brant Fabulae Bl. E 5b "De eo qui in fomnis aurum reperiebat".

Brant entnahm den schwank Poggio (L. 1798 "Aureum Somnium", Strasb. 1513 "De homine qui in fomnis aurum reperiebat"). Dals nicht letzterer, sondern wirklich Brant die vorlage war, beweist die lange moral, die sich bei Brant, aber nicht bei Poggio findet; man vergleiche:

Tibullus sayth: Dreames in the night hegylen and caufe fearfull myndes to drede thynges that neuer shal be. But yet Claudian sayeth. Dreames in sondrye wyse figured giveth warnyng of unlucky things ... as Hamylcar besiged the cyte of Syracule, he dreamed that he harde a voyce saye etc.
Tibullus ait: Somnia fallaci ludunt temeraria nocte et pauidas mentes falla timere iubent. Sed rurfus Claudianus: Somnia quinetiam variis infaufta figuris sepe monent. Nam et Carthaginensium dux Hamilchar cum obfideret Syracufas; inter fomnium fe exaudiffe vocem credidit nunciantem etc.

Den letzten teil der moral Brants hat der Engländer weggelassen und noch eine bemerkung hinzugefügt, worin er auf "G. Chauser's" "tale of the nounnes preste" und auf "the Boke of Fame" rühmend verweist. 
29. Of the crakynge yonge gentyll man, that wold overthrowe his enmyes a myle of. (S. 42.)

Quelle: Seb. Brants Fabulae Bl. F 6b "De armato nobili qui multa prefumebat led parum faciebat".

Brants eigene wörtlich benutzte vorlage war auch dieses mal Poggio. Es ist der in der Strafsburger ausgabe (Bl. 181 b) unter der aufschrift "De nobili quondam Friderici Imperatoris in armis prefumenti: fed nil facienti" und in der Londoner (s. 253) mit der bezeichnung "In Jactatores" gedruckte schwank. Brant und der Engländer enthalten die gleiche bei Poggio fehlende schlufsmoral:

There be many, whiche with their wordes slee theyr enmyes a great waye of, but whan they se theyr enmye, they put on a sure breste plate etc.

Multi longius abfentem hoftem verbis occidunt, quibus vilo holte miliaris fpatium folus falutare est thorace et lorica etc.

30. Of hym that fell of a tre and brake his rybbe. (S. 49.) [Er hätte nicht schneller herunter wie hinauf gehen sollen, dann wäre er nicht gefallen.]

Quelle: Brants Fabulae Bl. G 6 b f. "Facetiffimum confilium Minacii ad rusticum", Poggios "Consilium Minacii ad rusticum" (Str. $1513^{*}$ Bl. 161 b, L. 1798 s. 49), wörtlich entlehnt.

Beweiskräftig ist wieder die dem Engländer und Brant gemeinsame moral:

By this tale ye may note that abidyng and slownesse otherwhile are ... commendable specially in those thynges wherin spede and hastiness caufe great hurte and damage etc.
Docet hec fabula: moram tarditatemque nonnunquam effe commendandam prefertim his in rebus vbi feftinantia et acceleratio precipitium affere polfunt et damnum.

31. Of the frier that brayde in his sermon.

Quelle: Brant Fabulae Bl. E 1b "Predicator multum clamans quomodo confudebatur", getreu nach Poggios Concionatoris asinina vox (L., seite 234).

Die Stralsburger ausgabe hat die gleiche aufschrift wie Brant. Die abhängigkeit des Engländers von letzterem ergibt 
sich aus der bei Poggio fehlenden, den beiden anderen aber gemeinschaftlichen schlufsmoral:

.... which thinkynge for his brayenge lyke an asse to be reputed for the beste preacher, deserued well to here hym selfe to be compared to an asse.

For truely one to suppose hym selfe wyse

Is vnto folysshnes the very fyrste gryce. et cum concionatorem optimum clamoribus fuis afininis fe exiftimaret: audire fe parem effe afello commeruit. Credere enim fe fapientem primus ad ftultitiam gradus eft etc.

32. The oration of the ambassadour fent to Pope Urban. (S. 46.)

Quelle: Poggio In stolidum Oratorem (L., seite 132); ausgabe Strafsb. 1513 bl. 169 b "De oratoribus Perufinis ad pontificem Vrbanum".

Das englische schwankbuch folgte hier wie in den vorangehenden schnurren den vorlagen getreu mit gelegentlichen kürzungen oder unbedeutenden zusätzen.

Die moral am schlusse ist das eigentum des Engländers; allerdings ist sie sehr nichtssagend.

33. Of the ambassadour sent to the prince Agis. (S. 47.)

Quelle: Erasmus Apophthegmata gedr. 1531 (Ausg. Coloniae Gualthero Fabricio 1553) s. 36.

Obwohl der englische schwankdichter sich auf Plutarch beruft, so hatte er nicht sowohl diesen als vielmehr das sammelbüchlein von Erasmus vor sich, das er für diese anekdote ziemlich getreu benützte; man vergleiche:

... whan the ambassadour of the Abderites had at last ended a long tale to the prynce Agis, he asked what answere he shuld make to them that send him? etc.
Quum .. Abderitarum legatus apud Agidem multa loquutus, uix tandem dicendi finem fecilfet, rogaretque quid ciuibus fuis effet renunciaturus : etc.

34. The answere of Cleomenes to the Samiens ambassadour. (S. 47.)

Quelle: Erasmus, Apophtheg. (Col. 1553) s. 72.

Das verhältnis ist ähnlich wie bei der vorigen anekdote. 
35. Of the wise man Piso and his seruant. (S. 48.)

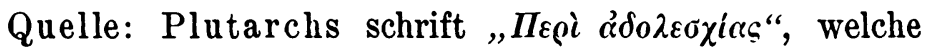
der verfasser dann jedenfalls aus einer lateinischen übersetzung kannte. Vielleicht schöpfte er aber aus des Erasmus schrift Lingua (gedr. 1525), worin (Opera Basel 1540 band IV, seite 563) die anekdote nach Plutarch mitgeteilt wird.

36. Of the marchaunt that made a wager with his lord. (S. 49.)

Quelle: Brant Fabulae Bl. B 6b "Quod dormientes multa non confiderant".

Brants vorlage war Poggios "Mulieris Crepitus" (L., seite 194) oder wie die aufschrift in den alten drucken lautet (Str. $1513 \mathrm{Bl} .175 \mathrm{~b}$ ) "De mercatore qui laudando uxorem liuam afferebat eam numquam ventris crepitum edidiffe".

Die abhängigkeit des englischen schwanks von Brant ist abermals durch einen bei ihnen allein zu findenden zusatz ersichtlich :

... it is an old sayenge: He that Vnde dici folet quoniam is qui dorslepeth, byteth no body.

mit neminem mordit.

Der übrige teil der schlufsmoral ist zusatz des Engländers, insbesondere auch der hinweis auf die Disticha Catonis, welche wir zu seinen quellen zu zählen haben. Übrigens weicht der Engländer insofern von Brant $a b$, als der kaufmann zweimal je "fifty crowns", bei Brant dagegen "quingentos aureos" zu leihen hat.

37. Of the friere that gaue scrowes agaynst the pestilence. (S. 51.)

Quelle: Brants Fabulae blatt B 8 a "De breui contra pestem ad collum fufpendendo", entnommen Poggios "Breue contra pestem" (L. seite 239).

In den alten ausgaben (so z. b. Strafsb. 1513 bl. 180 a) ist der titel wie bei Brant.

Die abhängigkeit des Engländers von Brant wird hier bewiesen 1. durch den namen des ortes: Tiburtine bei jenem, Tiburtina bei diesem und Tibur bei Peggio; 2. durch den jenen beiden ersten gemeinschaftlichen zusatz: 
DIE QUELLEN DER ENGL. SCHWANKBÜCHER DES 16. JAHRH. 475

By whiche tale one may lerne, that all is nat gospell that suche wanderers about saye, nor, enerye word to be beleued: For often tymes: -

Gelidus jacet anguis in herba.
Docet hec hiftoria: non omnibus fidem effe habendam que ab huiufcemodi circulatoribus fratercellis proclamantur neque omnia ipsorum credenda effe verba: plerumque etenim gelidus iacet anguis in herba.

38. Of the phisition that used to write bylles ouer eue. (S. 52.)

Quelle: Brants Fabulae bl. G 7 "Facetum cuiufdam medici forte medelas dantis dictum" = Poggios "Medicus vrinarius" (L. 211, Stralsb. 1513 bl. 177 a).

Brant und der Engländer haben den zufatz:

... miserable is their state whiche Mifera eorum conditio: quibus non fortune must helpe and nat reason. ratio fed fortuna opitulabatur.

38 a. Für das anhängsel: Pausanias und die Arzte benützte der Engländer drei apophthegmen aus der Erasmussammlung s. 102 (Col. 1533) nr. 21, 22, 23.

39. Of hym that wolde confeffe hym by writing. (S. 53.)

Quelle: Brants Fabulae blatt G 6 a "De faciente confessionem per fcedam" = Poggio "Mulcta peccati" (L., seite 187; Str. 1513 bl. 175 a "De quodam infulfo Mediolanenfi $q u i$ in fcriptis perrexit peccata fua facerdoti").

Brant und der Engländer enthalten wiederum den gleichen zusatz:

This confessour knewe well the Debuit enim fcire ... oris exigere ordinaunce ... whiche wylleth con- confessionem non fcriptura. fession to be made with the mouthe, and nat by wrytinge.

Bei Poggio und Brant wird die schnurre von einem Mailänder und einem mit namen angeführten Minoritenmönch erzählt, der englische schwank nennt weder ort noch namen.

\section{Of the hermite of Padowe. (S. 54.)}

Die quelle ist bei diesem schwank entweder Brant Fabulae G 8 b "De heremita qui multas mulieres stuprauerat" oder Poggio's "Eremita" (L., seite 151) in den älteren 
ausgaben "De Eremita qui multas mulieres in concubitu habuit" (Strafsb. 1513 bl. 171 b); beide stimmen vollkommen überein und Brant hat nichts hinzugefügt. Nachdem aber bei den vorhergehenden fabeln letzterer die vorlage gewesen, so dürfte es auch hier der fall sein.

\section{Of the Uplandisshe man that sawe the Kynge. (S. 56.)}

Quelle: Thomas Morus' epigramm "De Rege et Ruftico".

Das epigramm findet sich in der unten ${ }^{1)}$ beschriebenen ausgabe der Epigrammata des dichters auf seite 249, in den verschiedenen ausgaben seiner werke, ferner in verschiedenen sammlungen, so z. b. in Adrianus Barlandus' Iocorum veterum ac recentium libri tres (Col. 1529) bl. f 6 a, in den Flores Epigrammatvm des Leodegarius à Quercu, Tomus I (Lutetiae 1560) bl. 233 a usw.

- Um das verhältnis zwischen original und nachbildung zu veranschaulichen, stelle ich beide neben einander:

An vplandysshe man, nourysshed in the woddes came on a tyme to the citie, whanne all the stretes were full of people, and the common voyce amonge them was: The kynge cometh. This rurall manne, moned with noueltie of that voyce had great defire to se, what multitude honed to beholde. Sodaynly the kynge, with many nobuls and states before hym, came rydynge royally. Than the people all about stedfastly behelde the kynge and cryed aloude: God saue the kynge: God saue the
Rufticus in fyluis nutritus uenit in urbem, Rufticior Fauno, rufticior Satyro. En populus plena Itetit hinc, Itetit inde platea,

Vnaque uox tota, Rex uenit, vrbe fuit.

Rusticus infolita uocis nouitate monetur,

Quidnam ita refpectet turba, uidere cupit.

Rex fubito inuehitur, celebri praeeunte caterua, Aureus excelso confpiciendus equo.

1) De opti || mo reip. statu || deqve || noua infula Vtopia libellus ue || re aureus, nec minus falutaris $\|$ quam feftiuus clariffimi differtif \| fimique uiri THOMAE MORI in || clytae ciuitatis Londinenfis ciuis || \& Vicecomitis. || Epigrammata clariffimi $\|$ difertiflimique uiri THOMAE MORI . . Epigrammata Des. Eraf \| mi Roderodami. | Apud inclydam Bafileam. | .

354 seiten $4^{\circ}$ (die zählung ist nicht genau). Die epigramme beginnen mit eigener titelseite auf s. 165 und reichen bis s. 271. Auf dieser seite findet sich der buchhändler (Froben) und die jahreszahl (1518) angegeben. Vom nächsten blatte an beginnen die epigramme des Erasmus. (Exemplar in der universitätsbibliothek zu München.) 
kynge. This villayne herynge them crye so, sayde: 0 where is the kynge, where is the kynge? Than one, shewynge hym the kynge, sayde: yonder is he, that rydeth upon the goodly whyte horse. Is that the kyng, quod the villayne? what, thou mockest me, quod he; me thinke that is a man in a peynted garment.
Tum uero ingeminant, uiuat rex undique regem

Attonito populus fufpicit ore fuum.

Rufticus, 0 ubi rex? ubi rex eft? clamat. at unus,

Ille, ait, eft illo qui fedet altus equo.

Hiccine rex? puto me derides, rufticus inquit.

Ille mihi picta uefte uidetur homo.

42. Of the courtier that bad the boy holde his horse. (S. 57.)

Quelle: Thomas Morus' Epigramm "De aulico ridiculum". Epigrammata ausg. 1518, s. 253. Barlandus f 6 b.

Ich lasse wiederum die beiden texte folgen:

A courtier on a tyme that alyghted of his horse at an Inde gate sayde to a boye that stode therby: Ho, syr boye, holde my horse. The boye, as he had ben aferde, answered: 0 Maister, this a fierce horse; is one able to holde him? Yes, quod the courtier, one may holde hym well inough. Well quod the boye, if one be able inough, than I pray you holde hym your owne selfe.
Quum defcendit equo de circnmitantibus uni

Aulicus, hunc teneas quifquis, es inquit, equnm.

Ille ut erat pauidus dixit, domine ergo ferocem

Hunc rogo qui teneat fufficit unus equum?

Vuns, ait, potis eft retinere, fubintulit ille,

Si potis eft unus, tu potes ipfe tuum.

43. Of the deceytfull scriuener. (S. 57.)

Quelle: Brants Fabulae blatt G 1 a f. "De notario falso" = Poggio's "Notarii Fraus" (L., seite 178 Strafsb. 1513 bl. 174 a).

Brant und Mery Tales haben eine bei Poggio fehlende schlufsmoral:

By this tale ye may se that the Prudentiores ad conquirendam pechildren in this our tyme be very cuniam funt filij huius feculi etc. prudent to get money.

Übrigens hat der Engländer nur den ersten satz des moralischen schlusses verwendet. Bei Brant folgen noch sechs zeilen, in welchen auf Plinius und Juvenal verwiesen wird. Das lokal, Florenz, hat der Engländer in seinem schwank 
weggelassen, bei ihm ist nur von "A certauyne scrituener" die rede.

44. Of hym that saide he beleued hiss wyfe better than other, that she was chafte.. (S. 59.)

Quelle: Seb. Brant Fabulae blatt C 2 b "Vxoris fidem effe fequendam".

Die fabel ist Poggio entlehnt (Mariti Fides L., seite 147; Strafsb. 1513 fol. 171 a "Fabula Dantis | qui fepius uxorem fuam increpebat"). Dals der Engländer Brant folgte, beweist sein schlufssatz: This was well and wisely done: For one ought nat to gyue light credence to those thinges, wherin resteth perpetuall grefe of mynde, Poggio entlhält nichts dem entsprechendes, aber bei Brant lesen wir: "fapienter fane: quod non facile credere oportet his rebus quibus perpetuus potest inefle meror".

45. Of hym that payd his dette with crienge bea. (S. 60.)

Quelle. Wie schon längst bekannt, enthältt dieser schwank einen teil des stoffes der Farce von Pathelin.. Die englische version stimmt aber mit keiner der vorhandeneen darstellungen überein, betreffs deren verbreitung ich auf Boltte's ausgabe des Veterator (Latein. Literaturdenkmäler heft 15), Berlin 1901, praef. s. VII) und auf seine ausgabe des Wickramschen Rollwagenbüchleins (vgl. daselbst die nachweise :zu $\mathrm{nr}$. 36) verweise. Am meisten nähert sich der Engländesr noch Pathelin selber, besonders im letzten teil, im gespräclh zwischen dem anwalt und dem schuldner; aber auch früh@re stellen entsprechen solchen im Pathelin. Nun wäre es zwar nicht unmöglich, dals der verfasser des englischen schwankbuches den lateinischen Veterator oder Pathelinus kannte, da bis 1543 neun ausgaben erschienen waren, von denen reine ihren weg

- leicht nach England finden mochte. Um den iinhalt des fünfaktigen stückes in den engen rahmen eines kurzen schwankes von zwei seiten à 25 kleinen zeilen zu zwängen, mufste er gewaltig streichen und zusammenziehen und so wäre es verständlich, warum bei ihm vieles fehlt, was im Pathelin eine hauptsache ist, so Pathelins betrug dem kraufmann gegenüber, die konfuse gerichtsverhandlung usw. Eine genaue 
vergleichung derr drei texte ergibt aber die überraschende tatsache, dals einee grölsere ähnlichkeit zwischen dem französischen und engylischen, als zwischen dem lateinischen und englischen bestekht. Man vergleiche:

\section{Mery Tales.}

WWhat wylt thou gyue me; (quaod the man of lawe) if I ryddde the of this dette....

UWhan thou comest before: the Justice, what som euer $r$ be : saye vnto the, loke that thovu answere to nothing, butt cry p bea styl ...

SSo whan the fentence wass gyuuen the man of lawe drew $\mathrm{r}$ the e dettour asyde and said:: Lo, howe sayst thou nowe?? Hanue not I done well for the?? Thoou arte clere quitte of the 3 detitte that was demanded of $f$ thee: wherfore giue me myr monney, and God be with the.. Bera! quod he. What, quod thes lawweer, thou nedest not to cries bear no longer; thy matter iss disppatched; all is at a point,, theere resteth nothynge butt to gyue me my wages. Bea,, quaod he agayne.
Veterator.

(Veterator:) Quid tu mihi dabis? Cedo.

In ins ubi vocaberis, Statim nihil refpondeas Nisi Bee, quicquid ii tibi Dicant.

\section{Veterator.}

Ehodum.

Ad me! Tuane res hodie cessit tibi

Pulchre?

$$
\text { Opilio. }
$$

Bee.

Veterator.

Iam recessit adversarius,

Istuc bee mitte! Iam omnis est res in vado,

Sed dic mihi, nonne ille habet? Num consilium

Vt res erat, perquam bonum tibi dedi?

$$
\text { opilio. }
$$

Bee.

\section{Veterator.}

Cedo argentum mihi

Me tempus est abire.
Pathelin.

(Path.) Que donras-tu, si ie renuerse

Le droit de la partie adverse Et si je t'en envoye absoulz?

Jà tost quant on t'appellera Pour comparoir en iugement Tu ne respondras nullement For Bee, pour riens que l'on te die.

\section{Path.}

Vien çà, vien

Ta besogne est-elle bien faicte?

Le Bergièr.

Bee.

\section{Pathelin.}

Ta partie est retraicte, Ne dy plus Bee; il n'y a force. Luy ay-je baillé belle estorse? T'ay-je point conseillé à point?

Bee.

Le Bergièr.

Pathelin.

Il est jà temps que je m'en aille,

Paye-moi.

Le Bergièr.

Bee.

Wohl stündee nichts der annahme entgegen, dafs der Engländer das lateiinische stück kannte und einen auszug davon gab. Es hätte a aber schwierigkeiten anzunehmen, dals er den französischen Parthelin kannte. Er verrät nirgends kenntnis der französischem sprache, französische quellen finden sich sonst nicht bei ihm und so müssen wir uns mit der tatsache begnügen, dals deer schwank anklänge an Pathelin zeigt, aber 
unentschieden lassen, in welcher weise der stoff unserem erzähler vermittelt worden ist.

46. Of the woman that appeled from Kyng Philip to Kynge Philippe. (S. 62.)

Der erzähler gibt selbst Valerius Maximus als seine quelle für diese bekannte anekdote an. Er sagt: "This wryteth Val. Maximus. But Plutarche sayth, it was a man, and kynge Philip was halfe a slepe, whan he gaue fentence." Die anekdote findet sich bei Valerius VI, 2 Ext. 1.

Der Plutarch, auf den der Engländer hinweist, sind wahrscheinlich die Apophthegmata des Erasmus (Col. 1553 s. $260 \mathrm{f}$.), wo von einem gewissen Machaetas und Philip von Mazedonien die geschichte erwähnt wird. In den Apophtheg. des Erasmus s. 697 konnte der Engländer auch die erzählung des Valerius Maximus finden.

47. Of the olde woman that prayde for the welfare of the tyrant Denise. (S. 63.)

Quelle: Valerius Maximus VI, 2 Ext. 1.

Man vergleiche nachstehende zusammenstellungen:

$$
\text { Mery Tales. }
$$

... Whan he vnderstode that she so dyd, he meruailed greatly at her undeserued beninolence: wherfore he sente for her and asked why and howe he had deserued, that she prayde for him?

Andere versionen wie z. b. J. Gast I, 31 "De Aniculae oratione", Barlandus' Jocorum veterum ac recentium libri tres (Col. 1529) bl. b 6b wörtlich entnommen, stehen ferner; man vergl. die entsprechende stelle: "Audita et cognita, re, Dionysius, cum fciret tantam non deberi fuis beneuolentiam factis, mulierculam accerfit \& quid ita pro fe Deos ac coelum omne fatigaret, percontatus eft.

\section{Of the phisitian Eumonus. (S. 64.)}

Quelle: Eine äsopische fabel, deren griechischen text Nevelet in seiner Mythologia Aescopica (1610) s. 246 f. mit

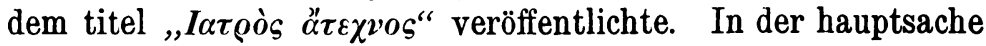
stimmt der englische erzähler mit dieser fabel, die richtiger 
als schwank oder epigramm zu bezeichnen wäre, überein. Aber wie soll er dazu gekommen sein? Nevelet führt sie unter den "Fabulae nunquam hactenus editae" an, und der Engländer verrät nïgends eine spur, dafs er Griechisch verstand. Hierzu kommen noch mehrere umstände, die die schwierigkeiten vermehren, so z. b. dafs in der englischen erzählung der arzt Eumonus, der patient Gaius heilst, während in der griechischen fabel namen fehlen, ferner dafs im ausdruck keinerlei berührungen stattfinden. Besonders das gespräch zwischen dem arzt und dem vermeinten toten weicht bei dem Engländer sehr von dem griechischen erzähler ab. Bei letzterem fragt der arzt gleich, wie es den gestorbenen gehe. Antwort: „Sie ruhen und trinken Lethes wasser. Neulich haben Thanatos und Hades schlimmes gegen die ärzte beschlossen, weil sie die kranken nicht sterben lassen; auch dich hatte man auf die liste gesetzt; ich habe ihnen aber zugeschworen, du seist kein arzt." Anders der Engländer. Der arzt frägt bei ihm den Gaius, ob er lebend oder tot sei. "Tot" ist die antwort. - Was tust du dann hier? - Gott hat mich geschickt, alle ärzte zu holen; aber fürchte nicht, sagte er zu dem erbleichenden Eumonus "there is no man that hath wytte that wylle take the for one". - Alles wohl erwogen, dünkt es mich am wahrscheinlichsten, dafs die fabel dem Engländer durch ein lateinisches epigramm übermittelt worden ist.

\section{Of Socrates and his scolding wyfe. (S. 65.)}

Der Engländer bezeichnet mit den worten "Laertius wryteth" selber seine quelle. Vergleichen wir ihn aber mit dieser, so finden wir, dalls die ähnlichkeit nicht sehr grols ist; man urteile selbst:

\section{Mery Tales.}

Laertius wryteth that the wyse man Socrates had a coursed scaldinge wyfe called Xantippe, the whiche on a daye after she hadde alto chydde him powred a **** potte on his heed. He takynge all paciently, sayde: dyd nat I tell you that when I herde Yantippe thouder so fast, that it wolde rayne anone after?

\section{Laertius.}

Xantippe cum in eum prius conuicia \& maledicta ingeffiffet, post vero \& fordidis aquis perfudiffet, Non ne, inquit, dicebam Xantippem tonantem quandoque pluituram? 
Näher als diese version steht dem Engländer die des Walter Burley in seiner Vita philosophorum, ich führe sie an:

Quodam vero tempore cum, infinitta convicia ex superia loco ingerente Xantippe, reticuillet, aqua per eam perfusus immunda, nil amplius refpondit quam ... "Sciebam", inquid, quod ista tonitrua pluvia sequeretmr.

Da Walter Burleys Vita ph. bisweilem mit Laertius verwechselt wird, so wäre es möglich, dals dies auch hier der fall ist. Oder sollte der Engländer, wie நbereits einmal oben, den namen Laertius nur dem Barlandus verdanken, der unter der aufschrift "Ex Laertio \& alijs quibusdam" (auf blatt b 8 b seiner Joci) die anekdote folgendermalsen bringt?

Socratis dictum.

Patientiffimus Socrates ille post multa ab uxore Xantippe iaculata in fe conuitia maledictaque lotio quoque \& urina perfusus, nonne inquit, dicebam pluituram quandoque Xantippen?

Auch Erasmus in seinen Apophth. (Col. 1553 s. 175) bringt das geschichtchen, aber im ausdruck noch weiter abstehend.

Wenn es nicht irgend eine version gibt, die der englischen erzählung näher als alle angeführten kommt, so wäre es denkbar, dals letztere aus Burley und Barlandus zusammengeflossen ist.

50. Of the phisitian that bare his paciente on honde, he had eaten an asse. (S. 65.)

Quelle: Brants Fabulae, blatt B 3 a f. "De medico indocto" = Poggio's Clitella (L. seite 113)), oder wie der titel in den alten ausgaben lautet: "De medico in vifitatione infirmorum versuto".

Im schwank selber stimmen Poggio umd Brant bis auf die sieben letzten worte des jüngeren autors "debitumque fatuitati fue et impericie cachinnum reportauit", die nur eine umschreibung des vorhergehenden "ad rifum excitauit" sind, überein. Da Brant eine moral bei diesem schwank nicht hinzugefügt hat, so hätten wir keinen anhaltspunkt, um zu entscheiden, ob er oder Poggio direkt die vorlage des Engländers war, wenn uns nicht ein umstand zu hilfe käme, nämlich der, dafs Brant jeder von ihm aufgenommenen fabel ein kleines gedichtchen vorausschickte, das mit ihrem inhalt in irgend einer 
beziehung stand. Es ist dies, abgesehen von der schlufsmoral, die er aber nicht überall anfügte, seine einzige selbständige zutat zu seiner ssammlung. Nun hat aber der englische schwankdichter imı vorliegenden falle das gedichtchen benützt; um daraus seine sschlufsmoral zu drechseln, somit Brant zur quelle gehabt. Maan vergleiche:

Thus as a good faithfull phisitian is worthy of greate honcour: for truely of hym dependethe the greattest part of mans helthe, so lyke wyse a folysshe and an vinlerned, that thynkethe to cure witth wordes that he ought to do with lherbes, is ... worthy to be derydedl and mocked etc.
Dignus honore quidem medicus bonus atque fidelis.

A medico pendet maxima nempe falus.

At medico indocto nil perniciofus viquam

Inque pudentius eft hoc homine vfque nihil,

Qui curare putat verbis, quod debuit herbis:

Ille vmbram monftrat etc.

51. Of the intholders wyfe and her II louers. (S. 67.) Die quelle cdieses schwanks ist wahrscheinlich Brants Fabulae blatt C $3 \mathrm{lb}$ f. "De callidate confilii muliebris". Da aber der Engläinder dieses mal weder von der moral noch von dem gedichtchien Brants gebrauch gemacht hat, so muls auch die möglichkceit bestehen bleiben, dals er Brants vorlage Poggio's "Mulieb)ris vafrities" (L. 273) (Stralsb. 1513 bl. $183 \mathrm{~b}$ : "Callida confilia Florentina foemine in facinore deprehenfes") benützt hat.

52. Of hym thiat healed franticke man. (S. 68.)

Quelle: Poggrios "Insanus sapiens" (L, seite 7) in den alten ausgaben (z. b. Stralsb. 1513) "De medico qui dementes \& infanıos curabat". Der nachahmer hat sehr stark gekürzt.

53. Of hym thiat sayde he was not worthy to open the gates to the kynge. (S. 70.) [Landmann vom könig vom England aufgefordert, ein tor zu öffnen, erklärt siich für nicht würdig und läuft fort, zwei meilen wreit, um einen würdigeren $\mathrm{zu}$ holen.]

Sollte auch diie quelle dieser anekdote in einem predigtmärlein $\mathrm{zu}$ suchen sein? 
54. Of mayster Vauasour and Turpin his man. (S. 70.)

Die quelle dieses schwankes wird wohl in England zu suchen sein.

55. Of hym that sought his wyfe agaynst the streme (S. 72.)

Quelle: Poggio's "Mulier demersa" (L., seite 69) (Str. $1513 \mathrm{bl.} 163 \mathrm{~b}$ "De eo qui uxorum in flumine peremptam querebat".

Der nachahmer hat hier eine moral nicht beigefügt, aber den zug, dals das weib starb "as she came ouer a bridge, fell into the ryuer and was drowned". - Brant, Fabulae bl. $\mathrm{C} 3 \mathrm{~b}$ hat auch die geschichte wörtlich nach Poggio, aber zusammen mit "Pertinacia Muliebris" (L s. 68). Auch Domenichi Facetiae (Ven. 1588) s. 54 hat sie aufgenommen; es liegt kein anlals vor, eine dieser versionen als quelle anzusehen.

56. Of hym that at a skyrmyshe defended him with his feet. (S. 73.)

Quelle?

67. Of hym that wolde gyue a songe for his dyner. (S. 74.)

Quelle: Poggio's "Viatoris vacui astutia" (L s. 266) (Str. 1513 bl. 182 b "De cantilena tabernariis placita").

Der nachahmer hielt sich wörtlich an seine vorlage und fügte nur am ende eine nichtssagende lehre hinzu. Die von Poggio eingefügten worte des italienischen liedes: "Metti mano alla borsa e paga l'oste" gab er folgendermalsen wieder:

Whan you haue dyned make no delaye But paye your oste, and go your waye.

58. Of the foole that thought hym self deed. (S. 75.)

Der herausgeber verwies hier auf Poggio's "Mortuus loquens", während er sonst Poggio als quelle nicht nannte. Indessen folgte der nachahmer nicht sowohl diesem (L s. 275, Strafsb. 1513 bl. 183 b) als vielmehr Brants Fabulae bl. M 3 b f. "De mortuo: viuo ad fepulchrum deducto: loquente et risum mouente". Poggio und Brant stimmen wörtlich überein; aber der nachahmer verrät seine quelle dadurch, dals 
er das gedichtchen Brants zum schlufswort verwendet; man vergleiche:

By this tale ye may se what the perswasion of many doth. Certaynly he is very wyse, that is nat inclined to foly, if he be stered therevnto by a multitude.
Sepe homines verbis perfuadent: que neque fiunt:

Nec funt facta: tamen credulus effe putat.

Integer ille quidem fapiens quoque: quem fatuum tres

Si feciffe volent: infipere efficient.

59. Of the olde man and his sonne that brought his asse to the towne to sylle. (S. 78.)

Quelle: Brants Fabulae bl. F 4 a "Qui parere cupit cunctis plerumque periclum Inde capit: damnum fuftinet atque graue", = Poggio's "Agaso" (L., seite 101, S. bl. 167 a "Facetiffimum de fene quodam qui afinum portauit fuper fe"). Die weltbekannte fabel ("Asinus vulgi"), die Poggio's gewährsmann in wort und bild in Deutschland gefunden haben will.

Dafs Brant quelle für den Engländer war, bezeugt die beiden gemeinsame moralische lehre am schlufs:

... they whiche commyt them selfe to the opinion of the common people, ben oppressed with great myserye and seruage: for how is it possible to please all whan euery man hath a dyuers opinion, and dyuersly iudgeth? and that was well knowen to the poet, whan he sayde:

Scinditur incertum studia in contraria vulgus etc.
Conftat nempe eos qui ad vulgi opinionem veniunt, miferrima premi feruitute: cum hand quaquam poffibile fit: cum diuerfa fentiant placere omnibus: diverfis diuerfa probantibus. Nouit hoc poeta cum ait. Scinditur incertum studia in contraria vulgus etc.

60. Of him that sought his asse and rode on his backe. (Seite 80 .)

Quelle: Brants Fabulae bl. D 2b "De eo qui querebat afinum quem equitabat"; Poggio's Fabula Mancini (L., seite 63, str. 1519 bl. 163a).

Die abhängigkeit des englischen schwanks von Brant beweist der moralische schlufs: "This jeste may be well applied vnto such as note the defautes that they lyghtly spy in other and take none hede nor can nat se, what ils they haue or bene spotted with them selfe." Der gedanke findet sich in dem gedichtchen, das Brant seinem schwank voranstellte:

Anglia. N. F. XIX. 
Queritur exterins id quod deprendiit intus

Impingifque aliis quod met inique facis.

Auch das von Brant hinzugefügte scchlufssätzchen besagt dasselbe: Multi itaque foris querunt quodd intus habent.

61. The answere of Fabius to Liuius. (Seite 81.)

Quelle: Erasmus Apophthegmata: (Col. 1553) s. 414 no. 21/22.

62. The answere of Poltis, the kiynge of Thrace to the Troyan embassadors. (SS. 82.)

Quelle: Erasmi Apophthegmata (Coll. 1553) s. 357, no. 34. Der Engländer bezeichnet Plutarche ails vorlage, worunter er aber, wie es scheint, eben Erasmus' Apoophthegmata versteht.

63. The wise answere of Hanibal to Kynge Antiochus, concerninge his ryche armye. (S. 83.)

Bei der grofsen verbreitung dieser anekdote ist es nicht leicht, mit völliger sicherheit die quellle zu vermitteln. Sie wurde zuerst von A. Gellius Noctes Att. 'V, 5 erzählt, wörtlich von Macrobius Sat. II, 2, 1 ff. wiederhoolt und ging in Joh. Sarisberiensis Policraticus u. a. werke ddes mittelalters über. Im 16. jahrhundert erzählte sie u. a. Erasmus in seinen Apophth., Barlandus in seinen Jocis (bl. b 4b) und nach Gellius auf bl. C 5 a f. usw. Der Engländter kannte wahrscheinlich alle diese autoren. $\mathrm{Da}$ er aber imı ausdruck dieses mal freier verfuhr, so ist der beweis, wem eer hier folgte, schwer zu führen. Ich glaube, dals er Erasmuss (Apophthegmata col. 1553 , s. 417 , no. 34 ) zur vorlage hatte, einmal weil die vorhergehenden zwei anekdoten sowie die nachufolgende der gleichen quelle entnommen sind und dann, weil die englischen worte "riche and sumptuous ... apparaile" mur bei Erasmus etwas einigermafsen entsprechendes in dem ausdruck "barbarico apparatu magnifice instructum" aufweisen. Bromyard, der die geschichte A XXIV, 2 bringt, stehtt dem engl. schwankdichter ferne.

64. The wordes of Poplius the Rosmayn embassadour to Antiochus the kynge. (SS. 83.)

Quelle: Erasmi Apophth. (c. 1553) sseite 445, no. 11. Die übereinstimmung hiermit ist eine vollkommene; der Engländer 
hat einfach Erasmuss übersetzt. Die bei Valerius Maximus vorkommende version। VI, 4, 3 weicht sprachlich von Erasmus und dem Engländer aab; letzterer hat sie also nicht benützt.

65. Of him that lioved the marchants wyfe. (Seite 84.) Quelle: Brantss Fabulae blatt C 8 b "Amatores mutos effe confpectu Venerre" = Poggio's "Mulieres Refponfum" (L. seite 252, Str. 15133 "Bellum mulieris refponfum ad iuuenem fuo amore flagrantem"'). Die abhängigkeit des Engländers von Brant bezeugt der scbhlufs:

"This maner of folye was weell knowen to the poet when he saydde: Incipit affari mediaque in voce reeliltit.
Nonit hanc amantinm ftoliditatem poeta cum ait: Incipit affari mediaque in voce refiftit.

Das einleitungsgeedichtchen Brants hat der nachahmer zum schlufs gereimt wiederrgegeben:

Folysshe loue maketh folkees astonied And eke to raue without remembrance

Whan they shulde speake, they bene abbasshed And of their wordes can I make non vttterance.

Nor be so hardye them selfe, to auance What tyme they se of her the swete face

Of whom the loue theyr haartes doth eenbrace.
Stultus amor Itupidos facit et fine mente furentes. Cunque loqui cupiunt: non potuiffe loqui.

Sed poftquam ille coram vultum conIpexit amice, Non audet, nec fcit verba cupita loqui etc.

66. Of the womam that couerd her heed and shewed her taile. ((Seite 86.)

Quelle: Brants Fabulae bl. C 5 a f. "De muliere que vt tegeret caput, pofteriojra detexit" = Poggio's Pudor muliebris (L., seite 144, Str. 151£3, blatt 171 "De muliere que cum caput cooperire vellet, culunm detexit"). Der schwank findet sich auch in der Mensa pohilosophica IV B, kapitel 42, von einer Beguine erzählt. Die abhängigkeit des Engländers von Brant beweist der schlufs:

This tale touchethe them that wolde couer a smalle offence with aa greatter wyckednesse; and as the prouerbe saythe: Stomble at a strrawe and leape ouer a blocke.
Hoc eos refpicit qui paruum delictum grandiori fcelere occultare querant, quemadmodum et is fecit qui incidit in feyllam dum vult vitare charybdim. 
Man beachte die glückliche wiedergabe des lat. sprichwortes durch ein englisches.

67. How Alexander was monysshed to slee the fyrste that he mette. (Reite 86.)

Quelle: Valerius Maximus Facta et Dicta memor. VII, 3 Ex. 1. Die abhängigkeit des Engländers von ihm ergibt sich aus stellen wie folgende:

If it be so, mighty kyng (quod the man) than the lotte dyuine hath ordeyned an other to suffre this deth and not me: for the lytel asse that I .. si ita eft, inquit, rex, alium fors huic morti deftinauit: nam assellus, quem ego ante me agebam, prior droue before me, mette you fyrste etc.

tibi occurrit etc.

68. How the cite of Lamsac was saued from destruction. (Seite 87.)

Quelle: Valerius Maximus Facta et Dicta VII, 3 Ext. 4. Die anekdote ist gleich der vorigen ziemlich wörtlich wiedergegeben, man vergleiche:

"Through whiche sage and subtile haec velocitas sagacitatis oppidum sayeng the noble auncient citie was uetusta nobilitate inclytum exitio, saued from ruyne and destruction. cui destinatum erat, subtraxit.

Andere versionen - ihre zahl ist legion - wie z. b. Petrarca (1. c.), Erasmus Apophthegmata (C. 1553) s. 538 usw. stehen ferner.. Nachweise durch Oesterley zu Pauli 508.

69. How Demosthenes defended a mayde. (Seite 88.)

Quelle: Valerius Maximus Dicta et Facta VII, 3, Ext. 5. Das verhältnis des Engländers zu dieser ebenfalls sehr verbreiteten anekdote des Römers ist das gleiche wie bei den zwei vorhergehenden.

Übrigens scheint der Engländer auch die version in den Apophth. des Erasmus (Col. 1553 s. 346) benützt zu haben, die, obwohl Val. Maximus entnommen, mehrfach davon abweicht.

70. Of him that desired to be made a gentilman. (Seite 89.)

Quelle: Poggio, "Rusticus nobilem se fieri petens" (L., s. 70) Str. 1513, bl. 163 b.

Der nachahmer hat den "Dux Aurelianencis" beibehalten ("duke of Orliance"), die anekdote aber etwas gekürzt. 
71. Of the gentyll man and his shrewde wyfe. (S 90.) Quelle: Poggio "Uxor litigiosa" (L. seite 88) (Str. 1513 bl. $165 \mathrm{~b}$ ) "De milite qui uxorem habebat, litigiofam".

Die vorlage hat der nachahmer wörtlich benützt; nur erzählt er den schwank nicht von einem Florentiner, sondern unbestimmt von "a certayne gentyll man".

72. Of the two yonge men that rode to Walsyngham. [Einer geht zuletzt fort, weil er sein pferd nicht kennt.] (Seite 91.)

Quelle: Poggio, Eques Venetus (L. seite 92) Str. 1513, bl. 166a "Iocatio cuifdam Veneti qui equum, fuum non cognouerat".

Der nachahmer hat den lateinischen schwank ziemlich getreu übersetzt, ohne zusätze oder merkliche weglassungen. Nur hat er die bei Poggio genannten namen und lokale durch entsprechende englische ersetzt. So machte er aus Antonius Luscus "one John Reynoldes". Während Luscus von Rom nach Vincentia reist, heifst es von Reynoldes "rode out of London ... towarde Walsyngham"; der "Venetus qui perraro ut uidebatur equitaffet" ist durch "a yonge man of the same cite (London)" ersetzt "that hadde not moche ben accustomed to ryde". Bei Poggio kehrt die gesellschaft in Siena ein, beim Engländer "they came to an Inne", nähere ortsangabe fehlt. So verstand es der nachahmer, seine erzählung geschickt zu lokalisieren und ihr das aussehen eines echt englischen schwankes zu geben.

73. Of the yonge man of Bruges and his spouse. (S. 92.) Quelle: Poggio, "Repensa merces" (L., seite 165) Str. 1513, bl. 173 a "De Florentino qui filiam vidue defponfauerat".

Der nachahmer hat seine erzählung verkürzt und vereinfacht, sich aber sonst an seine vorlage gehalten, nur verlegte er die handlung, die bei Poggio in Florenz spielt, nach "Bruges" und während Poggio ausdrücklich sagt, dafs sich des jungen mannes erste braut mit einem anderen vermählt, läfst sie der Engländer unverheiratet. Bei Poggio ist ferner die "prior fponfa" bei der hochzeit ihres gewesenen bräutigams 
anwesend und beide lachen, sich ihres abenteuers erinnernd, worauf die junge frau ihre frage stellt. Beim Engländer dagegen "he and his wyfe satte talkynge on a tyme of the forsayde dammusell" und "he fell in a nyce laughing", worauf sein weib ihn nach dem grunde befragt. Das sind änderungen, die nicht gerade als verbesserungen bezeichnet werden können.

\section{Of hym that made as he hadde ben a chaste lyuer. (Seite 93.) \\ Quelle: Poggio, "Mortificatio carnis" (L., seite 168)} Str. 1513, bl. 174 b "De quodam volente fe videri fumme caftitatis in adulterio deprehenfo".

Die anekdote ist ziemlich genau übertragen, nur wurde aus "Quidam ciuis noster" (also aus einem Florentiner) schlechtweg "A felowe"; ferner hat der nachahmer die moralische schlufsbemerkung gekürzt.

75. Of him that the old roode fell on. (S. 94.) [Er will deshalb nicht mehr zur kirche gehen.]

Quelle: Bromyards Summa Pracdicantium (Ausg. Ven. 1586, bd. I, bl. 43 a) CXVI, 6 .

Ich stelle vorlage und nachahmung hier zusammen:

Mery Tales.

As a man kneled vpon a time before an olde rode, the rode felle downe on him and brak his hede; wherfore he wolde come no more in the churche half a yere after. At lengthe by the prouocation of his nighbours, he cam to the churche agayne and .... he kneled downe .. and sayde thus: well I may cappe and kneele to the; but thou shalte neuer haue myn harte agayne as long as I lyue.
Bromyard.

.. hic cum federet in quadam ecclefia, imago crucifixi male ligata eius fregit brachium: ille ex hoc offensus, per annum ecclesiam intrare noluit, finaliter ad instantiam vicinorum dicentium quod nisi ecclesia intraret, esset sicut hereticus comburendus, timore coactus, uno die ante ostium ecclesiae venit .... Dicebat ... bene potero genuflectere \& caput inclinare et adorare, sed bonus amor ... inter nos nunquam erit.

Wie man sieht, bestehen zwischen beiden versionen auch kleine abweichungen. Pauli's Schimpf und Ernst, der sub no. 336 die gleiche anekdote nach gleicher quelle brachte, steht ihr viel näher. 


\section{Of the wydl 0 w that wolde nat wedde for bodily pleasure: (S. 95.)}

Quelle: Abstemius no. 31 "De Vidua uirum petente". Die vorliage des Abstemius war offenbar Poggio Conjugii pax (L. seitte 216) oder, wie der titel in den alten ausgaben (z. b. Str. 1177 b) lautet, "Mulier vidua quae cupiebat habere virum profecta aetate". Der Engländer benutzte aber dieses mal den sonst von ihm so stark geplünderten Poggio nichit, sondern wie erwähnt Abstemius; das beweisen die folgenden nebeneinanderstellungen:

Mery Tales.

There was a ryche widowe, whiche desyredde a gossyp of hers, that she wold get her an husband: not for the nyce playe, quod she, but to th'entente, he may kepe my goodes to gether ... Her gossyp whiche viderstood her conceyt, promised her to do so.
Abstemius.

Viidua quaedam diues a vicima petebat, ut maritum fibi incquireret, quem non coitus gratia, qui ingratus libi erat, fred ne bonae faa dilapidaremtur exoptare fe dicebat. Mulier fagax, et viduae verlfuttias intelligens, se inquifiturram pollicetur.
Poggio.

Mulier vidua cum diceret vicine: fe licet iam de vita huins feculi non curaret / cupere tamen virum profecta aetate focietatis potius \& communis vite fabfidij, quam alterius rei caufa .... Illa inventuram fe einsmodi virum pollicita etc.

77. Of the couetous ambassadour that wolde here no musike.. (S. 95.) [Er will aus geiz ihr ständchen nicht anhören, denn seine mutter sei gestorben. Freilich vor 40 jahren, wie er einem freunde später eingesteht.]

Quelle: Abstemius no. 22 "De Legato auaro tubicines decipiente.

Der Engländer mielt sich genau an seine vorlage, er übersetzte sogar die moralische lehre, fügte aber noch einige sentenzen über couetousmess hinzu, "wovon zwei aus den $A p o p h$ thegmata des Erasmuls genommen" zu sein scheinen (C. 1553 s. 229):

Diogenes calleth couetousness the heed of all yuels and sa:ynt Hieronyme (?) calleth couetousness the rote of all yuels.

Dicere (Diogenes) solebat cupiditatem esse malorum omnium arcem

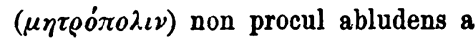
fentencia Solomonis qui dixit, cupiditatem radicem malorum oinnium.

Ob der übersetzer selbständig an stelle Salomons den hl. Hieronymus setzte order ob er irgendwo diesen mit dem ausspruch in verbindung gesetzt fand, will ich dahingestellt sein lassen. 
78. Diese nummer fehlt in Hazlitts : ausgabe, sei es, dals er sie vergessen hat, sei es, dafss sie schon in den alten ausgaben ausgelassen wordenı war.

79. How Denise the tirant serued a couetous man. (S. 97.)

Quelle: Erasmi Apophth. (Col. 11553) s. 365.

Dieses mal hat der Engländer sseine darstellung etwas breiter gehalten wie seine vorlage. MIan vergleiche:

Mery Tales.

It was shewed to Denise the tyran, that a couetous man of the cite had hyd a great some of money in the grounde, and lyued moste wretchedly: wherfore he sente for the man, and commaunded him to god dyg up the money and so to deliuer it unto him. The man obeyde and delyuered vnto the tyran all the gold \& treasure that he hadde, saue a small some ... where with he wente in to an other cite etc.

80. Of the olde man, that quengiered the boy oute of the apletree with stones. (S. 98.)

Quelle: Abstemius no. 91 "De: Sene iuuenem poma fibi furripientem faxis deiiciente:".

Der nachahmer schliefst sich eng an seine vorlage an, die er, einschliefslich der schlufsmoral, iins Englische überträgt. Anderen versionen, so z. b. der bereits 1538 gedruckten fabel des J. Camerarius Senex et Adolesccens (Fabulae Aesopicae Lpzg. 1564, seite 255), steht er ferner..

81. Of the ryche man that wolde not haue a glyster (S. 99.) [Weil es ihm am koupfe, nicht an der sitzstelle weh tut.] fante."

Quelle: Abstemius no. 63. "D)e viro cylsteria recu-

Auch diese fabel hat der Englämder einfach übersetzt; er liefs nur die bezeichnung "nationie Germanus" bei dem reichen kranken weg. 
82. Of hym that feyyed hym self deed to proue what his wyfe woldle do. (S. 99.) [Sie ifst zuerst.]

Quelle: Brants Frabulae blatt C 4 a f. "De fletu vxorum in morte viri".

Den schwank entnarhm Brant, wie zumeist Poggio. Es ist der Vir reviviscens (L. seite 123), in älteren ausgaben (Str. 1515 bl. 169a) "]De viro qui fue uxori mortuum fe oftendit".

Die abhängigkeit dees englischen schwanks von Brant geht auch hier aus dem - bei Poggio fehlenden - schlufssatz hervor:

Wherby ye may se, that nat without vnde haud ab re dictum eft: vt flea good skyl the poet sayde: Ut fle- rent oculos erudiere faos. rent oculos erudiere suos.

Die englische nachıahmung schliefst sich genau an die vorlage an, nur bezeichnet sie nicht den ehemann als "hortulanus" sondern, ohne angrabe seines berufs, als "A yonge maried man". - Domenichi hatt (Facetie Ven. 1588 s. 145 f.) die geschichte wörtlich aus Po)ggio übersetzt, so daโs man zweifeln könnte, ob Brant oder ter dem Engländer näher steht, aber der fehlende schlufssatz entscheidet gegen ihn wie gegen Poggio.

83. Of the poure man, into whose house theues brake by nygihte. (S. 101.)

Quelle: Menfa philiosophica buch IV, kap. 17. Ausg. Col. 1508, blatt 38 a, ausg. 16i02, s. 229.

Die gleiche fabel, ider Men/a philosophica entlehnt, befindet sich auch in den sschwänken Bebels (Opuscula $1514 \mathrm{Cc}$ ) "De Histrione". Aus Biebel schöpfte wörtlich J. Gast Convivales Sermones I, 126 unter gleichem titel. Thomas Morus hat den witz unter dem titel In fcurram pauperem in verse gebracht (Epigr. 1518 s. 261). Der Engländer steht der Men/a philosophica, Gast und Morus, die alle zu seinen quellen gehören, so ziemlich gleich nahe. Vielleicht kannte er alle versionen - die ich umten folgen lasse -, wenn ich die Mensa philosophica als quelle bevorzugte, so geschah es, weil ihr auch die drei forlgenden schwänke entnommen sind. 
Mery Tales.

There was a poore man on a tyme, the whiche vnto theres that broke into his house on night, he sayde on this wyse: syrs I maru ayle, that ye thynke to fynde any thing here by night: for I ensure you I can find nothing whan it is brode day.

\section{Menfa ph.}

Quidam histrio videns latrones in domo fua, dixit, nelcio quid vos hic potestis inuenire (in) nocte, cum ego nihil invenire poffim clara die.
Morus.

In fcurram pauperem.

Scurra vbi iam fures totam fibi nocte videret

Scrutanteis magna fedulitate domum

Rifit \& 0 media quid vos hic nocte videtis

Miror, ait; media nil ego cerno die.

\section{Gast:}

Quidam hiltrio, cum noctu quoldam fures in domo fua deprehendiffet, ait ad illos, Nefcio quid ros nocte hic inuenire uelitis, cum fereno die ego nihil inuenire poffim.

\section{Of hym that shulde haue ben hanged for his scoffynge. (S. 101.)}

Quelle: Mensa philosophica (gleiches kapitel wie das der vorigen anekdote; ausg. Col. 1508, bl. 38 a, ausg. 1602 s. 230.) F. W. D. Brie (Eulenspiegel in England, Berlin, Mayer \& Müller 1903 , s. 77) glaubte die quelle dieses schwankes in einer verschmelzung der 17. und 29. historie des englischen Eulenspiegel gefunden zu haben; allein es ist kein zweifel, dals der verfasser der Mery Tales ausschliefslich der, wie wir sahen, auch sonst von ihm benutzten Mensa philosophica folgte; das beweist die nachfolgende zusammenstellung:

\section{Mery Tales.}

There was a mery felowe in hygh Almayn, the whiche, with his scoffynge and iestynge, had so moche displeased a great lorde of the countreye, that he thretned to hange hym, if euer he coude take hym in his country. Nat longe after, this lordes seruauntes toke hym, and hanged he shulde be. Whanne he sawe there was now remedy but that he shulde dye, he sayde: my lorde, I muste nedes suffre dethe, whiche I knowe I have wel deserued. But yet I beseke you graunte me one peticion for my soule[s] belthe. The
Menfa phil.

Cum quidam histrio contra nobilem quendam multa opprobria ironice dixiffet, ita quod illi fufpenfum minaretur vbicunque eum apprehenderet, tandem a fuis comprehenfus dixit: Domine, ego video quod non reftat nifi mori, quod latis merui, fed faciatis vnam petitionem folam, quae femper melius proderit animae meae. Qui victus precibus circumstantium conceffit petitionem fiendam. Tunc ille ait, peto, Domine, qũ nunc fum fufpenfus, vt tribus diebus inmediate fequẽtibus de mane ieiuno ftomacho veniatis \& ofcule- 
lorde, at the instaunce, of the people that stode abonte, so it dydde not concerne his lyfe, was contente to graunde it hym. Than the felowe sayde: I desyre you, my lorde, that after I am hanged, to come III mornynges fresshe and fastynge, and kysse me on the bare ****. Where vnto the lorde answered: the denyll kysse thyne $* * * *$ : and so let hym go.

85. Of hym that had his goose stole. (S. 102.) [Der bestohlene klagt es dem pfarrer, der in schlauer weise den dieb ermittelt.]

Quelle: Mensa philosophica (IV. b. kap. 16 "de Latronibus"). Col. 1508, bl. 37 b, ausg. 1602 s. 226.

... So on Sontay the curate as ... cum in die Domenica facerdos though he wolde curse, wente up in admoneret de eo, ait, ledeatis omnes. to pulpit and bade euery body syt Et cum fe omnes federe dicerent, downe. So, whan they were set, ait, non fedetis omnes. Certe, inhe said: why sit ye nat downe? quit, non, quia ille non fedet, qui We be set all redy, quod they. furatus eft anferem. Imo, ait, fedeo. Naye (quod the curate) he that dyd Subintulit facerdos: Tu ergo statim stele the goose sitteth nat. Yes, ei reddas anferem, alias te excomthat I do, quod he. Sayste thou that? quod the curate, I charge the, on peyne of cursing, to bring the goose home ageyn. municabo.

86. Of the begger that sayd he was kyn to kyng Philip of Macedone. (S. 103.) [Verwandter von Adam her.]

Quelle: Mensa philosophica IV. b. kap. 6 "de Regibus" (Col. 1508, bl. 34 a, ausg. 1602 s. 205).

There came a begger to kyng Philip of Macedone on a tyme and prayde the kyng to gine hym some what; and farther he sayde he was his kynse man And whan the kyng asked hym which way, he answered and sayde howe they came bothe of

Regi fummo Philippo occurrit quidam Ribaldus, petens vt fibi daret, quia cognatus fuus effet. Quefinit rex ex qua parte? Et ille de Adam inquit. Rex iuffit ei dare eleemofynam etc.

Adam. Than the kynge commanded to gyve hym an alms etc.

Belustigend ist es, wie der nachahmer aus dem Rex summus Philippus, worunter entweder Philipp von Schwaben oder ein 
könig von Frankreich zu verstehem ist, den ihm offenbar allein bekannten $\mathrm{Ph}$. von Macedonien miachte. Über die ungeheure verbreitung der anekdote bis in dire neueste zeit kann ich hier nicht handeln.

\section{Of Dantes answere to the iester. (S. 103.)}

Quelle: Poggio, Responsio Dantis (L., seite 66) Str. 1513, bl. 163a "Refponfio elegans D'antis poetae florentini" oder vielleicht Brants Fabulae bl. D 5 b Dantis Florentini faceta refponfio. Die entscheidung ist in diesem falle unmöglich, weil beide vorlagen textlich fast bis aufs letzte wort übereinstimmen. Der Engländer folgt jedenfalls wörtlich einem von beiden.

\section{Of hym that had sore eyes. (S. 104.)}

Quelle: Morus (Thomas) De Fusco potare (Epigrammata s. 248 f.). Man vergleiche:

\section{Mery Tales.}

One that had sore eies was warned of the phisitian that he shulde in any wyse forbeare drinking or els lose his eies: to whom he sayd: it is more pleasure for me to lose myne eies with drinkynge than to kepe them for wormes to eate them oute.
Morus:

Potando medicus perituros dixit ocellos

Frfco: qui, cum fe confuluiffet ait: Perdere dulcius eft potando, quam ut mea feruem

Erodenda pigris lumina vermiculis.

89. Of the old woman that had sore eyes. (S. 104.)

Die quelle dieses schwankes dürfte schwerlich eine einheitliche sein. Der Engländer entlehnte den anfang wahrscheinlich der fabel des Remicius "Mulier et Medicus", die im 16. jahrhundert von 1521 an sehr verbreitet war; man vergleiche :

There was an olde woman the whiche bargayned with a surgean to heale her sore eyes and whanne he hadde made her eies hole and that she sawe better, she convenaunted that he shulde be payde his money and not before.
Mulier anus dolens oculos conduxit Medicum quendam mercede, conuentiione facta, fi fe curaret pactam mercedem ei daturum: fin autem minime nihil daturam.

Für den rest der fabel hielt er sich an das epigramm des Thomas Morus "De Chirurgo et Anu" (ausg. 1518 s. 257). 
So he layde a medycyne to her eyes, that shulde not be takken awaye the space of $\mathrm{V}$ dayes, in whiche tyme she mighte not loke vppøe. Euery daye, when he came to diresse her, he bare awaye some what of her hausholde stouffe, table clothes, candlestickes and disshes. He left no thinge that he coullde carye clene. So whan her eies were hole, she loked vp and sawe that lher householde stouffe was caryede :awaye.
Vnxit anus aegros nelans chirurgns ocellos,

$\nabla$ tile perfuadens hoc fore quinque dies.

Interea mappas, pelues, mortaria difcos,

Quicquid onus tutum non facit, inde rapit.

Quum fanata oculos circumtulit illa reuinctos

Inftrumenta fuae fentit abefle domus.

Man findet die fiabel in griechischen texten, ferner bei Camerarius (1564) s. 835, bei Dorpius no. 401, bei B. Waldis III, 54, Cognatus (aussg. 1567) 107, Faernus no. 68, Men/a philosophica IV, kap. 444, Kirchhof Wendunmuth I, 112 etc.

90. Of hym that had the custodi of a warde. (S. 106.)

Die quelle ist centweder Poggios Tutor (L., seite 204) Str. bl. $176 \mathrm{~b}$ "Cuiujৎdam tutoris factum" oder Brants Fabulae bl.D 4 "De Tutore qui rationem tutele reddere jussus erat". Der ttext ist bei beiden der völlig gleiche. Ich glaube indes, daiss Brant die vorlage war, weil der titel des englischen schwankrs mehr ähnlichkeit mit dem seinigen hat.

Man möchte übrig̨ens vermuten, dafs dem Engländer auch die version des Johanmes Gast Sermones Convivales I, 290 "De Tutore malo" (aus 10. Luscinius Sales Iocique no. 143 geschöpft) bekannt war,, weil er mit diesem in einem sätzchen übereinstimmt, das beii Brant und Poggio fehlt, nämlich:

and to gyve accompte of thee orphlins juffus tutelae geftae ratione reddere. goodes.

Es ist indes wahrrscheinlicher, dals die stelle durch die aufschrift des schwanlks bei Brant veranlalst wurde. - Domenichi, der die geschiichte auch und zwar nach Gast bringt, steht dem Engländer ganz ferne.

91. Of the excellemt paynter that had foule children. (S. 106.)

Quelle: Der Englländer schöpfte diese anekdote entweder aus der Mensa philosopihica IV. buch, kap. 45 (ausg. 1602 s. 292, Col. 1508, bl. 48 b), oderr aus Gasts Convivales Sermones I, 221 
"De Pictore" (der selber den schwank aus Luscinius Ioci ac Sales no. 198 entlehnte) - denn beide bücsher kannte er; wenn er nicht etwa Macrobius Saturn. II, 2, 10, die quelle aller dieser direkt benützte.

Während alle diese versionen die anttwort von dem römischen maler Mallius erzählen, der von seimem freunde Seruilius Geminus interpelliert wurde, hat der Eingländer - was er offers tut - die namen weggelassen. - Die anekdote befindet sich auch bei Barlandus (blatt $A$. 2 b) mit dem namen Manlius und nochmals (aus Pontanus' Dle Sermone geschöpft) bl. C 1 b. 1)

92. Of the fcoffer that made a man a south sayer (S. 107.)

Quelle: Poggio, "Divinatio" (Go)nella) L., seite 174; StraIsb. 1513 fol. 173 b, oder Brants Fabulae bl. G 2b "De eo qui socium fuum fecit prophetam" (zweite erzählung). Welcher von beiden vorlage war, ist schwer $\mathrm{zu}$ emtscheiden, weil beide wortwörtlich übereinstimmen, soweit es; sich um die erzählung handelt. Brant hat allerdings eine lange moral hinzugefügt. Da aber eine solche beim Engländer fehlt, so ist dieser umstand für die quellbestimmung :nicht zu verwerten.

1) Das thema mufs bei den humanisten des 15. und 16. jahrhunderts sehr beliebt gewesen sein, denn man findet es hänfig in der epigrammendichtung. So hat z. b. Conrad Celtis (5 Bücher Epigr. hg. v. Hartfelder, Berlin Calvary 1881, IV, 84, s. 91) ein epigramm ituber den gegenstand unter dem titel "De pictore deformem prolem generante", worin von Mallius oder Rom nicht mehr die rede ist. Niicolaus Bartholomaeus ans Loches, ein franz. humanist, verfafste das nachstehende gedichtchen.

De pictore.

Rogatus olim pictor a me perfpiccax, Quid tam infolentes iple natos gïigneret, Qui pingeret Spectabiles imaginess, Quas procreandis multi haberent liberis: Depreffa tam funt (inquit) haec ,duo inuicem, Quam nox aperto coeca differt a die.

Nos luce pingimus, tenebris fingiimus.

Anch Bromyard J, VII, 1 hat ganz kurz dies anekdote, steht aber dem Fngländer ferner als die obigen. 
DIE QUELLEN DERR ENGL. SCHWANKBÜCHER DES 16. JAHRH. 499

93. Of the marchant of Florence called Charles (S. 107.)

Quelle: Entwweder Poggio "Salse Dictum" (L., seite 251) ausg. Str. 15113, bl. 181 a "Salsum hominis dictum contra mercatoreem alios acculantem", oder Brants $\mathrm{Fa}$ bulae, bl. D 6 af. "C`ontra mercatorem alios accufantem". $\mathrm{Da}$ der Engländer seiner erzählung keine moral hinzugefügt hat und Brant und I Paggio im schwank bis aufs letzte wort übereinstimmen, so , ist auch hier eine entscheidung unmöglich.

94. Of the cheesshire man called Eulyn. (S. 108.) [Trunkenbbold vergilst sein im wirtshaus eingeschlafenes kindd und tröstet seine jammernde frau, ertrunken ssei es nicht, er hörte es nicht ins wasser plumpen.]

Quelle?

95. Of hym that desired to be fet vpon the pillori. (S. 109.)

Die quelle dieeses gaunerstreichs dürfte wohl in England zu suchen sein.

Die keckheit, 1 mit der die beutelschneider hier zu werke gehen, erinnert an Des Perriers Nouvelles Recréations no. 80, "Des mesmes coupeeurs de bourses, et du prevost La Voulte.

96. Of the wydlowes daughter that was sent to the abbot with a couple of capons. (S. 111.)

Quelle: Wahrsscheinlich ein mündlich verbreiteter klosterwitz.

97. Of the two men that dranke a pynte of whyte wyne to ggether. (S. 112.)

Quelle: Wahrsscheinlich ein mündlich erzählter kneipwitz.

Ich erwähne, daafs diese anekdote bis in unsere tage fortlebt, ich hörte sie: wiederholt, zuletzt vor ein paar jahren, erzählen.

98. Of the docstour that went with the fouler to catche byyrdes. (S. 114.)

Quelle: Entweeder Poggio Aucupium (L., seite 190) Str. 1513, bl. 175 b "De. Doctore qui litterali fermone loque- 
batur in auibus capiendis \& indoctus erat" oder die daraus wörtlich geschöpfte fabel Brants bl. B 5 a "Stultitiam non poffe occultari". Da Poggio und Brant auch nicht die leiseste verschiedenheit aufweisen, wenn man von der aufschrift absieht, so ist es nicht zu entscheiden, wem der Engländer folgte; doch spricht die wahrscheinlichkeit für Brant, weil diesem auch die beiden folgenden nummern entnommen sind.

99. Of hym that vidertoke to teache an asse to rede. (S. 115.)

Die quelle ist hier Brants Fabulae bl. B 7 a "Differe rem difficilem falubre sepe eft". Obwohl Brant vollkommen im text mit Poggios Asinus erudiendus (L. 258, Str. 1513 "Facetum hominis dictum afinum erudire premittentis") übereinstimmt, so hat er doch ohne zweifel die vorlage für den Engländer gebildet, denn in dem englischen schlufsfatz "... It is holesome to take leyser inough about a thynge that is harde to do, specially whanne a man can nat chose to take hit on hande" ist nur für die erste hälfte das entsprechende bei Poggio zu finden: "salutare effe rem difficilem in longum protrahi". Dagegen beginnt das einleitungsgedichtchen bei Brant:

Magna salus homini eft rem quam vitare nequibit

Protahere etc.

100. Of the fryer that confessed the woman. (S. 116.)

Die quelle dieses weitverbreiteten schwanks ist entweder Poggio, Braccae Divi Francisci (L., seite 236) (Str. 1513 bl. 179 b "De reliquiis bracharum cuiufdam Minoris") oder Brants Fabulae C 6a blatt "De reliquiis bracharum cuiufdam Monachi".

Auch hier ist es schwer eine entscheidung zu treffen. Ich glaube indes, dals Brant die vorlage war, weil seine schlulsworte genauer zum Engländer stimmen als die des Poggio.

Mery Tales.

But after, whanne this was knowen, ambassadoures of the same citie went and complayned therof before the Holy See Apostolyke.
Brant:

Detecto poltmodum dolo: oratores eius vrbis | ad fedem apostolicam | queltum eam iniuriam venerunt.
Poggio.

detecto poitmodum dolo o10ratores eius urbis queftum eeam iniuriam uenerunt. 
Andere versiomen wie Sabadino 39, Sachetti 207, Massuccio I, 3 stehen fermer.

101. How a chaplen of Loven deceyued a vsurer. (S. 118.)

Quelle: Erassmus Colloquia fam. (Opera Basel 1540, bd. I, s. 647) und zwar das Convivium fabulosum. Die geschichte wurde von J. Gastt, wörtlich in seine Convivales Sermones aufgenommen (I, 300), so daIs es zweifelhaft sein könnte, ob dieser oder die Colloquia fam. vorlage des Engländers gewesen, da aber die nachfolgemde erzählung, aus dem dort angegebenen grunde Gast nicht entlehnt sein kann, so dürfte auch für diese erzählung Erasmus; selber als quelle anzusehen sein.

Der Engländerr hielt sich ziemlich genau an den text seiner vorlage und brachte nur ein paar kleine kürzungen an.

102. Of the same chaplen and one that spited him. (S. 119.)

Quelle: Erassmus, Colloquia fam. (Opera Basel 1540, bd. I, s. 648). Da (diese erzählung in der ed. princeps von J. Gasts Convivales Stermones (Basel 1541) fehlt, in späteren so z. b. in der ausg. Biasel 1554, 1566 nur halb steht, so mufs die sammlung als quelle für diesen schwank ausscheiden. Der Engländer benützte irgrend eine ausgabe der Colloquia fam. oder eine übersetzung, alber im engen anschlufs an dessen text, nur etwas gekürzt; hier eine probe:

\section{Mery Tales:.}

... one asked, whiche was the most reuerent part of mans lbodye? One sayd the eie, an other the nose; but Antony, bycause he knew his enuyer wolde name the clence contrarye, sayde the mouth was the most renerent parte. Naye, quod his enuyer, the parte that we syttce on is the most reuerent; and biicause they maruayled whye, he made this reason, that he was mcoste honourable amonge the comimon people that was fyrst sette; anid the parte that he named was ffyrste sette. Whiche sayenge contentred them and they laughed merelye.

Anglia. N. F. XIX.
.. hic Itatim nata eft quaeltio, quae nam effet hominis pars honeftiffima. Alius diuinabat oculos, alius cor, alius cerebrum, alius item aliud: \& fuae quifquam diuinationis rationem adferebat. Antonius juffus dicere fententiam dixit os fibi uidere partem omnium honeftiffimam: \& addit caufam nefcia quam. Tum alter ille, ne quid ipfi conueniret cum Antonio refpondit, eam partem qua ledemus, fibi uideri honeftiflimam. Quum id nideretur omnibus abfurdum, attulit hanc caufam, quod is diceretur nulgo honoratiffimus, qui primus confideret, hoc honoris competere parti quam dixiffet. Applaufum eft huic fententiae \& rifum eft affatim. 
103. Of the olde man that put hiim selfe in his sonnes handes. (S. 121.)

Quelle: Diese alte geschichte ist in zahllosen vielfach von einander abweichenden versionen in der predigtliteratur sowie in der vulgärdichtung des mittelaltcers verbreitet und gehört bis in die neuzeit zu den themen derr volkserzählungen. Unser erzähler stimmt auffallend mit der von W. J. Thoms in der Altd. Blätt. II. band (Lp. 1840) s. 811 mitgeteilten lat. erzählung aus dem 13. jahrh. überein, die err, nur etwas mehr ausgeführt, wiedergibt:

\section{Mery Tales.}

There was a certayne olde man, whiche let his sonne to mary and to brynge his wyfe and his chyldren to dwelle within him, and to take all the house in to his owne hand .... So a certeyne tyme the old man was sette and kepte the vpper ende of the table; afterwarde they sette him lower, aboute the myddes of the table; thyrdly they set him at the nether ende of the table; fourthly he was set amonge the seruantes; fifthly they made him a couche behynde the halle dore, and cast on him an olde sacke clothe. Nat longe after, the olde man died etc.
ILat. Erz.

Quidam senıex permisit filium suum se vivente uxxorem ducere et filios procreare in domo sua. Pater vero per aliquid ttempus sedit in capite mense, deindce in medio, $3^{\circ}$ in finem, $4^{0}$ inter famullos, $5^{0}$ post aule ostium, habens lectulium et super illum quemdam pannum saccinum quo operiebatur. Morittur senex etc.

Ich weifs nicht, geht diese fassung :auf Bromyard oder eine andere ähnliche sammlung zurück, voon denen Oesterley zu Pauli's Schimpf und Ernst no. 436 esine anzahl angibt. Sein zitat Bromyard K 8, 5 erwies sich ials irrig. ${ }^{1)}$ Jedenfalls haben wir in obiger lat. fassung dice vorlage des Engländers zu sehen.

104. Of hym that had a flye peynted in his shilde. (S. 122.) [Den ihn verhöhnenden antwortet er, er wolle so nahe an die feinde herantreten, dals sie sein wappen unterscheiden werdlen können.]

1) Ich habe nachträglich die stelle in Bromyaurd gefunden. Sie steht $R$ (edditio) III, 5, ist ganz kurz (nur 7 halbzeilen) und ist inhaltlich völlig von der version der Mery Tales verschieden. 
Die quelle dieieser anekdote wird vielleicht ein lateinisches epigramm gewesen s sein, oder eine in England verbreitete dem verfasser mündlich $i$ bekannte anekdote.

Der in der beieigefügten moralischen lehre gebrachte ausspruch des Archidarmus geht auf Erasmus Apophth. (Col. 1553) seite 52 no. 55 zurürück; die schlufsworte hat der Engländer einfach übersetzt: $\mathrm{n}$ man vergleiche:

$$
\text { Mery Tales.'s. }
$$

... but whan they comeie and fyghte hande to hande apperereth who be men and who be not.

105. Of the empperour Augustus and the olde men. (S. 123.)

Quelle: Vielleieicht Gast Convivales Sermones I, 13 "De Adriano uidente : feruum fe ad marmor affricantem". (Gast selber entnahihm wörtlich die anekdote Barlandus' Joci bl. d 1 a.) Die einzizige schwierigkeit, welcher diese annahme begegnet, ist, dafs ; der Engländer die geschichte vom kaiser Augustus und Gast.t-Barlandus sie von Adrianus erzählt. Es liegt aber die vermmutung nahe, dals der nachahmer sie absichtlich dem bekanmnteren monarchen zuschreiben wollte. Natürlich ist es auch 1 möglich, dals Barlandus selber quelle für den Engländer war,r, nachdem ihn dieser, wie bei no. 111 gezeigt werden wird, : sicher kannte.

\section{Phocions o oration to the Athenians. (S. 123.)}

Quelle: Erasismus Apophth., s. 322,3. Der nachahmer übersetzte fast wörtrtlich; man vergleiche:

$$
\text { Mery Tales. s. }
$$

Phocion on a daye $t$ treatynge a long oration to the peoplele of Athenes plesed them very wel; ; and whan he sawe, that they allill to gether allowed his wordes, he e tourned to his frendes and sayd: 1 have $I$ vnwarely spoken any hurtete? etc.

\section{Apophth.}

Quodam die (Phocion) orationem habens apud Atheniensem populum, placebat omnibus; quumque nideret ab omnibus pariter fermonem approbari, conuerfus ad amicos: Quid, inquit, num mali quippiam dixi imprudens? etc.

\section{Of Demosthhenes and Phocion. (S. 124.)}

Quelle: Erasmmus Apophth. s. 322, 5. Hier ist das gleiche verhältnis zwischen n nachahmer und vorlage wie in der vorigen anekdote. 
108. Of Phocion that refused Alexaniders gyfte. (S.124.) Quelle: Erasmus Apophth. s. 323, 8..

Da die eben angeführten charakterrzüge Phocions sich

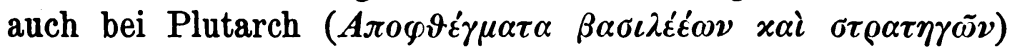
finden und dem Engländer, falls er nicht Griechisch verstand, durch eine lateinische übersetzung Plutaarchs vermittelt sein konnten, so sei erwähnt, dafs bei dieser lletzten anekdote der Engländer eine moral hinzugefügt hat, diee nicht bei Plutarch, aber wörtlich bei Erasmus vorkommt; maan vergleiche:

Who wolde not wonder at the cleane and vncorrupt courage of this Phocion? He was but a poore man, and yet the greatness of the gyft coude nothinge moue him. Besyde also he shewed that they the whiche, while they mynistre the common welthe etc.
Iam quiss hic non admiretur incorrupti pectoris fynceritatem? panper erat Phhocion, nec doni magnitudine quiccquam mouebatur. Simul autem indiacat, illos qui quum remp. administrennt etc.

109. Of Denyse the tyranne and hlis sonne. (S. 125.)

Quelle: Erasmus Apophth. s. 362, 33. Das verhältnis des Engländers zu dieser vorlage ist das gleziche wie in den vorhergehenden anekdoten: er übersetzte wöörtlich.

110. Of Pomponius the Romayne that was broughte before Mithridates. (S. 1255.)

Quelle: Erasmus Apophth. s. 534 ((ausg. Col. 1553.)

Der nachahmer übersetzte nahezu wcörtlich und fügte nur am ende eine kurze schlufsbetrachtung won zwei zeilen bei.

\section{Of Titus and the iester. (S. 1126.)}

Quelle. Nachdem der englische erzzähler anhebt: "Suetonius sheweth that Titus the father prouoked a scoffer etc." werden wir wohl Suetonius als seine vorliage anzusehen haben. Freilich findet sich der scherz auch in Fracetien- und Apophthegmensammlungen, so z. b. in Petrarcass De rebus memorandis Lib. II kap. 4 (Opera Basel, Petri 1554, ‘20, seite 478) und bei Barlandus Joci blatt $68 \mathrm{~b}$. Da Barlanduss in den scholien, die er seinen schwänken beifügte, zu dem voorliegenden (auf blatt C 6 a) bemerkt: "Non abfimilis eft iocus Mar(tialis) in Phoebum Vtere lactucis, \& mollibus utere maliuss Nam faciem duram Phœbe cacantis habes", so muls der Englländer neben Suetonius 
auch ihn gekannt habben, da er schliefst: "On suche a vifaged man writeth Martiallll":

Utere lacctucis, ac mollibus atere malins

Nam faciiem durum Phebe cacantis habes.

112. Of Scipio Niasica and Ennius the poete. (S. 126.) Quelle: Erasmnus Apophth. s. 526 no. 49. - Der nachahmer hat den lateinnischen text einfach übersetzt.

Whan Scipio Nasica cicame on a tyme to speake with EEnnius the Poete, he asked his maxyde at the dore, if he were withina; and she sayde, he was not at hhome. But Nafica perceyued that her master badde her say so, and thhat he was within etc.
Scipio Nasica qunm ad poetam Ennium neniffet, eique ab oftio quaerenti Ennium ancilla dixiffet eum domi non effe, Nafica fenlit illam hoc domini iuffu dicere \& illum intus effe etc. ${ }^{1}$ )

\section{Of Fabius Minutius and his sonne. (S. 127.)}

Quelle: Erasmus Apophth. s. 523 no. 34. Gleich der vorhergehenden anekddote wörtlich inklusive der moral benützt.

(113b.) An diese kurze "tale" hat der Engländer noch eine notiz über den kaiser Antoninus Pius angereiht: "Th' emperour Antoni[n]us. Pius loued moche this sentence of Scipio which wolde ofte sayre: I hadde leauer saue one citezen than slee a thousande ennemmyes." Diese stelle ist Erasmus Apophth. s. 480 no. 4 entlehnt.

114. Of Aurelianı that was displeased bycause the cite Tynaı was closed agaynst hym. (S. 128.)

Quelle: Erasmıus Apophth. s. 493. Wörtlich übersetzt aber mit weglassung i des schlufsbemerkung des Erasmus "Videtur autem hic sermoonis color etc."

1) Fast ganz mit denn gleichen worten erzählt Barlandus den witz. Da bei ihm indes nur Nassica statt Scipio Nasica steht und Erasmus in ein paar kleinigkeiten näher : als Barlandus dem Engländer steht, so glaubte ich jenen als vorlage bezeitichnen zu sollen. 


\section{Abteilung.}

\section{Zusatz-schwänke der ausgabe, von 1567.}

115. Of the nunne forced that dursst not crie. (S. 129.)

Diese erzählung findet sich auch beei Pauli Schimpf und Ernst (Oesterley's ausgabe, anhang no. 233) und zwar zuerst in der Strafsburger ausgabe von 1538, no. 4198.

Die quelle des Engländers ist aber Gast Convivales Sermones I, 194 Monachi iocus pafchaliis, wörtlich benützt, mit hinweglassung der drei einleitungszzeilen. Oesterley hat diese (aus Erasmus' Ecclesiastes s. 212 gescchöpfte) version nicht angeführt.

116. Of him that sayde he was the Divelles man. (S. 129.) [Dafür gibt er sich :aus, nachdem es ihm schlimm ergangen ist, als er ssich zuerst für einen anhänger Eduard IV. und danm Heinrich VI. ausgegeben hatte.]

Die quelle dieser anekdote dürffte in England $z u$ suchen sein.

117. Of the vplandishe priest. (S.. 130.) [Predigt, dafs ohne "charitie" niemand in iden himmel kommen könne, ausgenommen "the kymges grace, God saue hym".]

Auch die quelle dieses schwankes ist wahrscheinlich in England zu suchen.

118. Another sayinge of the same priest. (S. 131.) [Behauptet verfasser des nellenı testaments sei könig Heinrich VIII. "God haue merrcye vpon his soule!"] Quelle wie den beiden vorigen.

119. Of the fryer that praysed sainct Frauncis. (S. 132.) [Der mönch weils keinen platz, der gut genug für ihn wäre. Ein kircchenbesucher will ihm seinen kirchenstuhl überlassenı.]

Quelle: Gast, Convivales Sermonces (I, 197) "De Monacho Franciscum fuum super omnies chorus cœlitum praeferente". Auch diese anekdote wurde von dem nach- 
ahmer fast wörtlichb benützt. Ich stelle hier das ende der beiden versionen zusisammen:

And staying a lyttell : whyle, hee cryed out at laste sayininge: Where shall we place this holy, father? A frowarde felowe standyngg among the audeynce, saide: if thou canst find none other, than set hyym here in my place: for I am weanry. And so

Hic quum hæreret laudator, \& fubinde rogaret, ubi collocabimur patrem noftrum, quidam e turba morofior, Si deeft, inquit, locus, colloca illum in locum meum, fimulque abiit e concione.

went his way.

Gast selber schäöpfte aus der schrift des Erasmus "Ecclesiastes siue de ratione concionandi" s. 264/65.

Die gleiche aneekdote hat auch Bebel buch II, 81 (ausg. $1514 \mathrm{Gg} 4$ a De quoodam minore), aber dieser steht dem Engländer ferner. So ] heilst z. b. die entsprechende stelle bei Bebel: Atque deinceeps de choro ad chorum ducens, cum non inueniret locum, quao tantum virum locaret, furrexit quidam rusticus: si non potees aliter, pater bone, loces eum ad locum meum. Ibo enim add cauponem, tedio fcilicet affectus etc.

120. Of hym thant warned his wife of wasshynge her face in fioule puddell water. (S. 132.)

Quelle: Gast, , Convivales Sermones s. 51 "Concionatoris fabula pascchalis" (entlehnt Erasm. Eccles. s. 211). Der Engländer schloofs sich seiner vorlage wörtlich an, nur liefs er die einleitennden worte weg. Zur veranschaulichung des verhältnisses zwivischen original und nachahmung lasse ich nachstehendes folgenn:

A man dwellyng in the countrey takynge his iourney bad : his wife in his abfence playe the goorod husewyfe that he at his home comnyng might finde all thyngs well. - - - To be brefe, it tempted hir soo, that she wasshed, that is she ( defiled hir face. She loked in the glasse and was greatly displeased witith hir self.
Maritus quidam ruri uiuens, peregre abiturus mandanit uxori, ipfo ablente curaret ut reuerfus domum omnia reperiret ex animi fententia. .... Quid multis? uicit tentatio, lauit, hoc est, contaminauit faciem, confuluit fpeculum, displicuit fibi etc.

Domenichi, der in seinem Facetie die gleiche elzählung (nach Gast) bringt, ststeht dem Engländer im ausdruck ferner. 1) Nachweise gab Boltee zu Montanus Gartengesellschaft no. 7.

1) Man vergleiche: Un certo contadino effendo per andar difcofto commandò alla moglie, chbe mentre egli ftaua fuori, hauefle ben cura di cafa. 
121. Of the husbandman that causeed the iudge to geue sentence agaynst him s6elf. (S. 134.)

Die erzählung geht, aber wahrscheinlilich mittelbar, auf Cognatus, Sylva Narrationum (zum ersteen mal c. $1537 / 38$ gedruckt), ausgabe Genevae 1552 seite 111 "De praetore quodam, qui contra fe litem dedit", zunrück. Hier ist ein ort nicht genannt und die erzählung schliefsst mit den worten des landvogts (praetor) "Isthaec alia res ' eft". Beim Engländer spielt die sache in "Zeland" und naachdem "the ruler" gesagt hatte: "this is another matter", saggt der arme mann: Verily it is all one thing: and you haue trumely iudged. Auch ist die moral bei beiden verschieden. Wir kkönnen daher nicht Cognatus als die direkte vorlage ansprechenn.

122. Of the Italian friar that shouldd preach before the B. of Rome and his carrdinals. (S. 134.) [Robert Liciensis.]

Quelle: Gast, Convivales Sermones s.s. 53/54 "De Concionatoribus", zweiter teil, wiederum wöörtlich übertragen; man vergleiche die folgenden stellen:

... beinge in the pulpit and beholdyng the bishop and his cardinals enter into the churche with so great pompe, noise, and rufflyng, that no king vse[d] the lyke and seyng the bishop borne by VI men, and beynge at great leysure set downe, and harkenyng what he would say, he sayd nought elles but this: Phy on St. Peter! Phy on S. Paul! and with rauyng he spit now on the right syde, and nowe on the left syde etc.
... Erat apuiud illos dicturus, quos cum videret $f$ tftrepitu plusquam regio ingredi deniquue \& Pontificem geftari hexaphoro .... ubi tandem confediffent iamqque expectaretur nox hominis, is ninihil aliud proluquutus: Phy fanctum । Petrum, phy fanctum Paulum, fubbinde cum execrantis uoce expuensis, nunc in dextrum, nunc in finiftifram etc.

Gast schöpfte selber aus Erasmus' EEcclesiastes siue de ratione concionandi (gedr. 1535), ausg. Lugd. 11543 s. 488, welches buch dem Engländer auch selbst vorgelegeen haben könnte.

- Che u'ho io a dire pia, la tentatione la uinfe; cella fi lauò con quefta acqua; anzi per dir meglio, fi lordò tutto il vifo. Guaardandofi dunque nello fpecchio, uide come fi era mal concia etc. - Dommenichi Facetie, Venet. 1588 s. 22. 
123. Of the ddoctor that sayd in Erasmus workes were heeresies. (S. 136.)

Quelle: Erassmus. Diese anekdote sowie die folgenden drei sind offenbar 1 theologischen streitschriften von oder über Erasmus entnomme:en, wahrscheinlich das erstere; aber es war mir zu zeitraubendd, darnach in den neun riesenfolianten der Opera des Rotterdamer humanisten zu suchen.

124. Of the fifrier that preached at Paules crosse agaynstit Erasmus. (S. 137.)

Ebenfalls irgennd einer schrift des Erasmus entlehnt.

125. Of an otther frier that taxed Erasmus for writyngg German theologia. (S. 138.)

Quelle: Erassmus. Diese anekdote könnte der Engländer auch in Gast's Co'onvivales Sermones I, 202 gefunden haben, wo sie unter der auufschrift "De indocto Monacho" mit der quellenangabe "Erøas." vorkommt. Zur veranschaulichung des verhältnisses zwiscichen original und nachahmung, stelle ich nachstehendes zusanmmen:

Mery Talesss.

A fryer that preacheied on a tyme to the people, inveigighed greatly agaynste Erasmus, becalause he, in his booke called Enchiridilion preysyng the Apostles doctrynee, said that theirs was Germana theneologia, that is to saye in Englishe tlthe very right diuinitee. Lo (sayeth 1 this dotishe fryer) here may ye see, , what a man Erasmus is: he sayeth, l, there is no diuinitee but in Germonnye.
Erasmus Gast.

.... Theologus ordinis Francifcani ... (Res .. acta eft publicitus magnoque tumultu) protulit ex meis libris aliquot damnatas fententias. Quarum una fuit (Scripleram in Enchiridio, ni fallor) Haec eft uera germanaque theologia, quæ \& philosophorum fupercilia \& regum fceptra fubiecit Chrifto. Hic dira uociferabatur in meum nomen, qui negarim ufque effe ueram Theologiam præterquam in Germania.

126. Of an otheer that inueighed against the same Erasmuss. (S. 138.)

Quelle: Erasnmus.

127. Of king IRichard the III and the Northern man. (S.). 139.)

Für diese nichtitssagende kleine anekdote haben wir wohl an eine englische voorlage zu denken, vielleicht an eine stelle in einer chronik. 
128. Of the Canon and his man. (SS. 140.) [Er schilt
[En den jungen edelmann, weil er deen gästen bei tisch kein brod vorsetzt. "Hätten sie res nicht gegessen", sagt der "gentilmans sonne", „so wääre genug brod da."]

Vielleicht mündlich übernommen.

129. Of the same Canon and his sajyd man. (S. 140.) [Weitere ungeschicklichkeit dess6elben jünglings.]

Gleiche quelle.

130. Of the gentilman that checkedl hys seruant for talke of rynginge. (S. 141.) [Er kann besser über das läuten zu London sprrechen, denn er ist dort gewesen "an $\mathrm{C}$ alhalow ny६ghtes".]

Ohne zweifel dürfen wir hier gleichffalls eine englische und zwar mündliche quelle annehmen.

131. Of the blynde man and his boyy. (S. 142.)

Quelle: Die gleiche erzählung, nur mehr ausgeschmückt, findet sich in des B. Waldis Esopus buch IV, fabel 92 unter dem titel "Vom Blinden und seinem krnaben". Heinrich Kurz, der in seinen nachweisen zu den falbeln des Waldis bei dieser nur auf eine jüngere version verwejisen konnte, meinte betreffs der quelle des deutschen dichters:: „Vermutlich nach mündlicher überlieferung". Diese angabe istt, wie so viele andere des Kurz, falsch. Waldis hatte offenbar eine gedruckte vorlage für seine erzählung und vielleicht eime mit der des Engländers gemeinschaftliche lateinische.

132. Of him that sold two lodes of hey. (S. 142.)

Für diese erzählung mit echt englischer einkleidung werden wir wohl eine englische quelle, sei es reine mündliche oder irgend eine scherzhafte volkstümliche diichtung anzunehmen haben.

133. How a mery man deuised to cal people to a play. (S. 145.)

Auch für diese erzählung, die für diie äufsere geschichte des englischen theaters vor Shakespeare beachtung verdient, 
DIE QUELLEN DEER ENGL. SCHWANKBÜCHER DEg 16. JAHRH. 511

hat der unbekannnte sammler entweder die mündliche überlieferung oder einoe nur in England $z u$ findende schriftliche aufzeichnung zur qquelle gehabt.

134. How the image of the dywell was lost and sought. . (S. 148.)

Die quelle dieeser anekdote ist mir schon irgendwo einmal unter die hand gelkommen; ich entsinne mich aber im augenblicke nicht mehr, wo.

135. Of Tachaas, King of Aegypt and Agesilaus. (S. 149.)।

Quelle: Eraismus Apophth. s. 29 (aus Athenaeus entlehnt). Zur verannschaulichung des verhältnisses zwischen original und nachbbildung folgende probe.

Tachas beholdyng Aggesilaus to bee a man of so litel staturee ... tauntyng hym with this scoffe? sayde: The mountayne hath tranaqyled, Jupiter forbode, but yet hee haathe broughte forth a moufe.
Agesilaus ... quoniam corpore erat pusillo his uerbis a rege (Thaco) contemptus eft: Parturiit mons, Inpiter metuit, ut ille peperit murem.

136. Of Corar the Rhetorician and Tisias hys scoler. (S. 150.)।

Quelle: Die bbekannte anekdote des altertums. Corax das ist die richtigge form des námens - und Tisias, beide Sizilier, werden gevwöhnlich als die erfinder der redekunst, d. h. als die ersten bezceichnet, welche sie nach bestimmten von ihnen aufgestellten! grundsätzen lehrten. Die vom Engländer hier berichtete geschhichte findet sich viel in griechischen texten, so z. b bei Zenobiuss (Walz, Rhetores graeci IV, 82 und 129), bei Max. Planudes PPrologg. (Walz V, 215), bei Sextius Empiricus Adversus Mathematticos II, 96 (lat. übersetzung von Gentiano Herveto Aurelio Anntv. 1569 fol. seite 69). Dagegen habe ich sie bei römischen :schriftstellern bis jetzt noch nicht aufgefunden, wenn die beiden namen auch oft von ihnen erwähnt werden, so z. b. boei Cicero, Quinctilian, Martianus Capella, Victorinus Rhetor, usw. 
Dagegen findet sich bei Aulus Gellius die gleiche erzählung von Protagoras und Euathlus berrichtet. Johannes Sarisberiensis nahm sie in seinen Policraticus (ausgabe Lugd. Batav. 801595 seite 256 f.) auf, erzählte sie: jedoch von Pythagoras und Euvallus (oder Euathlus). Aultus Gellius (Noctes Atticae V, 10) gibt noch an, dafs die Griechen derartige streitargumentationen $\alpha \nu \tau \iota \sigma \varrho \varepsilon ́ \varphi o v \tau \alpha$ nannten. - Die letztere version findet sich auch bei Hemmerlin "de Nobilitatte" c. 34, bei Pauli 119 usw.

Nachdem der Engländer nirgends kenntnis des Griechischen zeigt, so mufs er eine lateinische vorlage, aum wahrscheinlichsten die lateinische nacherzählung eines humanisten gehabt haben. Der umstand, dals er Corar statt Corax schrieb, lälst darauf schliefsen, dafs seine quelle gothissch gedruckt war, denn nur so erklärt sich die verwechslung won $\mathfrak{r}$ und $\mathfrak{x}$. Nahe kommt ihm die von Lodovico Guicciardini (Hore die Recreatione 1572, s. 22 erzählte anekdote "L'arte dee luderfi con l'arte". Da er mit diesem oft gemeinschaftliche quelllen hat, so könnte es auch hier der fall sein; das einzige bedenken ist, dals Guicciardini die namensform Sosio statt Tisias bietet. Das könnte aber eine willkürliche änderung vom ihm sein, wie er sie sich oft gestattet. Im ausdruck kommen sich der Engländer und der Italiener oft nahe; hier eime probe:

So whan he had lerned the art, he made no haste to paye his teacher, wherfore hys mayster sued hym. Whan they came before the indges, the yonge man demaunded .. what was the effecte of the scyence? He aunswered : ... to perswade. Than .. if I perswade these .. indges, that I owe you nothing, I wil pay you nothing; for you are cast in your action. And yf I can not perswade them, than wil I pay you nothing because I haue not yet perfectly learned the art.
Ma hauendiola .. appresa, non roleua fodisfare; per il che Corace il chiamò in griustitia. Sosio .. domanda in chœ confifta la Rettorica: rifponde Corace .. nel perfuadere. Adunque dice Sosio, fe io perfuado à giudici di mon ti douer dar niente, io non ti pagtuerò cofa alguna, perche io haro, vinta la lite; fe io non gli perfuado, io unon ti pagherò, perche io non harò iimparato à perfuadere.

137. Of Augustus and Athenodorus the Philosopher. (S. 151.)

Quelle: Erasmus, Apophthegmata s. 288/89. Die vorlage wurde vom verfasser in gleicher weise wie die übrigen aus den Apophthegmata entlehnten stücke benützt. 
138. Of the ffrenche kyng and the brome seller. (S. 152.) ) [Um einem armen "brome seller" zu helfen, befiehlt ( ein französischer könig den höflingen, nicht ohne "al new brome" vor ihm zu erscheinen. Der brome sseller verkauft seinen ganzen vorrat und wird so wohlhabend.]

Auf die quellle dieses schwankes, die ich früher kannte, kann ich jetzt nicbht kommen.

139. An other tale of the same french kyng. (S. 153.) [Bewerbeer um ein amt, von Ludwig XI. kurz abgewiesenn, dankt, weil er nicht hingehalten wurde; erhält daas amt.]

Quelle: Erassmus, Colloquia fam. (Opera 1540 s. 646/47), aber wahrscheinlichh der völlig gleichlautenden version in Gasts Sermones Convivaleies I, 173 entlehnt. Der englische schwankdichter hat dieses I mal viel breiter erzählt und kleine zusätze gemacht. Sagt Errasmus: “quidam, petens ut munus, quod forte uacabat in eo ] pago, in quo habitabat, iuberet (Ludouicum) in ipfum transferrii", so drückt das der Engländer folgendermafsen aus: "Therce chaunced in a certaine part of the realme, an offyce to fal intto the Kings handes by the deth of a man which was worth $\&$ a CCCC crounes by the yere. An honeft witty gentilman, idwelling therby, trusting to obtayne the sayde offyce, made: as good speede to the courte as hee could, and as soone as hee might come to the Kyngs presence, he kneled downe, andd in most humble wise defired his grace to geue vnto hym that offyce, declaring what it was." Auch Domenichi (จテ. 1588) s. 76 hat die erzählung nach Gast; aber er steht dem Engländer nicht näher; er enthält keinen ausdruck, der nur ilihm und den Mery Tales gemeinsam wäre.

140. What an IItalyan fryer dyd in his preachyng. (S. 155.) [Predigt als krieger gekleidet - seiner geliebten 1 zu gefallen.]

Quelle: Gastt, Convivales Sermones I, 53, De Concionatoribus, erster t teil. Der Engländer übersetzte dieses mal wörtlich ohne zusättze oder weglassungen. Hier eine probe: 
Being sente for of the Cardinals with whom he was familiar, he was asked what was the pretence of that new example. He answered, that he did it for his wenches pleasure, who familiarly confessed that nothynge in the sayd Robert displeased hir, saue his friers coate. Then saide he to hir: In what apparell shal I best plese you etc.

Gasts eigene quelle ist die schrift des Erasmus De ratione concionandi (ausg. Lugd. 1543) s. 437.

Wenn wir das ergebnis dieser einzelnem untersuchungen kurz zusammenfassen, so müssen wir die 114 - oder richtiger 113 - nummern der Editio princeps und die 216 zusatznummern der ausgabe von 1567 aus einander halten. In der ersten ausgabe sind 18/19 verschiedene quellen benützt, die sich folgendermafsen verteilen:

1. S. Brants Fabulae in 27 nummern (22, 26, 28, 29, 30, $31,36,37,38,39,40,43,44,50 ; 51,58,59,60$, $65,66,82,90,92,93,98,99,100)$ ).

2. Poggios Facetiae in 17 nummern $(1,2,3,4,5,6,18$, $32,52,55,57,70,71,72,73,74,87)$.

3. Erasmus Apophth. in 15 nummern (33), 34, 61, 62, 63, $64,79,106,107,108,109,110,11.2,113,114)$.

4. Mündl. oder unermittelte engl. quellen in 14 nummern $(12,13,14,15,17,27,53,54,56,94-97,104)$.

5. Gasts Conv. Sermones in 7 oder 8 nummern (19, 20, 21 (?), 23, 24, 25, 105).

6. Abstemius' Fabulae in 7 nummern (7, 9, 10, 76, 77, 80, 81.)

7. Thomas Morus' Epigrammata in 5 nummern (11, 41, 42, 88,89 [halb]).

8. Valerius Maximus in 5 nummern $(46,47,67,68,69)$.

9. Mensa philosophica in 5 nummern $(83,84,85,86,91)$.

10. Barlandus' Joci in 3 nummern (49 [Laertius?], 105 [?], 111). 
DIE QUELLEN DERR ENGI. SCHWANKBÜCHER DES 16. JAHRH. 515

11. Bromyard jim 2 nummern (8 und 75).

12. Ein anonymes predigtmärlein in 1 nummer (103).

13. Erasmus' Limgua und Coll. fam. in 3 nummern $(35,101$, 102) ewemtuell in 4 weiteren nummern $(19 / 20,23 / 24)$.

14. Eine englisscthe ballade in 1 nummer (16).

15. Ein lat. epigramm bezw. alte fabel in 1 nummer (48).

16. Pathelin (e)vent. mittelbar) in 1 nummer (45).

17. Gellius Nocctes Atticae in 1. nummer (21?).

18. Vielleicht ILaertius in 1 nummer (49 ?)

19. Vielleicht Swetonius in 1 nummer (111).

Bei den 26 zusatznummern der ausgabe von 1567 haben wir acht verschietdene quellen anzunehmen:

1. Mündliche order in England zu suchende: 10 (116, 117, $118,127,128,129,130,132-134)$.

2. Gasts Conv. Sermones: 6-7 (115, 119, 120, 122, 125 [?], $139,1410)$.

3. Erasmus Opeerca: $3-4(123,124,125$ [?], 126, 139 [?], 140 [?]).

4. Erasmus Aprophth.: $2(135,137)$.

5. Ein predigtmärrlein: 1 (131).

6. Cognatus (miittelbar): 1 (121).

7. Fine griechissch-lateinische anekdote: (136).

8. Die quelle vron no. 138.

Die zusammenstellung ist von interesse; sie zeigt uns einmal, wie belessen der verfasser der Mery Tales war und dann, dafs die zusıatzerzählungen in der überwiegenden mehrzahl quellen entnommen war, die schon in der ersten ausgabe benutzt worden w:aren. Dies legt die vermutung nahe, dals der verfasser der ersten ausgabe auch zugleich der verfasser der zusätze ist, ejine vermutung, welche, wie ich gleich bemerken will, durch eine sorgfältige vergleichung der erzählweise und des stiils der älteren und jüngeren schwänke bestätigt wird. Wir dürfen uns also zwischen der ausgabe von 1567 und der ältesren undatierten keinen zu grofsen zeitlichen abstand denken. Wir wären mit dieser bemerkung bei der frage nach der diatierung der letzteren angelangt, die nicht 
so leicht zu entscheiden ist, als Hazlitt, BBrie und Köppel es sich dachten.

Was Hazlitt veranlafste, den druck „cc. 1535 “ zu setzen, weils ich nicht; vielleicht verfuhr er, derr die ausgabe sah, schätzungsweise. Brie schliefst sich ihm an. Köppel, der den druck ungefähr ins jahr 1549 verlegen ı will, dürfte hierzu vielleicht dadurch veranlafst worden sein, idals er die Facetie Domenichi's für eine der quellen des englisckhen erzählers hielt. Diese Facetie kamen "a IX d'ottobre MDXILVIII" zum ersten male ans licht und so ergab sich das dattum „c. 1549“ ganz von selbst. Nachdem aber die Facetie Doomenichi's, wie ich gezeigt zu haben glaube, nicht zu den quelllen der Mery Tales gehören, so fällt das datum c. 1549 zusammeen, wenn sich nicht neue stützen dafür ergeben.

Fragen wir zunächst, ob der text derr Mery Tales keine historischen anspielungen enthält. Die ersten 113 Tales, d. h. die Editio princeps keine. Dagegeen bieten die 117. und 118. erzählung - also zwei der zussatzerzählungen angaben, die zu einer datierung der letztereen, freilich zu keiner genaueren, führen. Der schlufs von 118 laqutet: "That dyd ... kynge Henry the eyghte, God haaue mercye vpon hys soule". Da Heinrich VIII. 1547 staarb, so kann diese erzählung nicht früher geschrieben sein.. Der schlufs der Tale 117 lautet: "it was impossible foor any man to be saued or to come to heauen without charitie, except onely the Kynges grace, God saue hhym". Hieraus ergibt sich, dals die erzählung vor Juli 1553 bereits geschrieben war, d. h. noch zu lebzeiten könig Eduard VI; denn von 1553 an bis zum ende des jahrhunderts konnte: man nur von "the Queens grace" reden. Somit fällt die entsstehungszeit der zusätze zwischen 1547 und 1553. Das zwvingt uns aber zur annahme, dals zwischen der ausgabe vonı 1567 und der undatierten eine zweite zwischen 1547-1553 eerschienene existiert haben mufs, die die 26 zuzatzgeschichtern zum ersten male brachte und von der die ausgabe von 15667 nur ein abdruck war. Eine solche annahme hat nichts auuffallendes für alle jene, welche wissen, wie ungeheuer selten schwankbücher des 16. jahrhunderts und besonders englische ssind, die oft nur in einem defekten exemplar oder nur in einemn kleinen bruchstück vertreten sind. 
Wann erschien \& aber die Edit. princeps? Eine annähernde zeitbestimmung gestitatten uns die quellen der schwänke. Die jüngste dieser wäree, wenn sie sicher eine quelle ist, Gasts sammlung. Die Coonvivales Sermones erschienen zum ersten male unter dem naamen Joh. Peregrinus 1541 zu Basel, in zweiter Auflage 15442 daselbst "Mense Aug.", in dritter und zum ersten male mnit dem namen Joh. Gast 1543, in vierter 1545 usw. Vor 15ら42/43 dürfte das buch seinen weg nach London kaum gefunoden haben. Früher könnten wir also den druck der Editio pprinceps nicht setzen, vielleicht aber noch ein paar jahre späteer, so dafs zwischen ihr und den zusatzerzählungen tatsächhlich kein grofser zeitlicher abstand wäre und Köppel's datieerung der wahrheit näher käme als diejenige Hazlitts. Diee sache bleibt indes zweifelhaft.

Das datum liefsse sich und vielleicht mit gröIserer genauigkeit, auf einem andderen wege, nämlich auf dem bibliographischen, ermitteln. Dijazu bedürfte es aber bei der grolsen seltenheit englischer druckke des 16. jahrhunderts auf dem kontinent, eines aufenthalts in JLondon. Ich will hier wenigstens den weg andeuten, der meinees erachtens dabei einzuschlagen wäre.

Die Editio prinaceps erschien, wie Hazlitt am schlusse der 114. erzählung angibibt:

"Imprinted at London in Flete Strete in the house, of Thhomas Berthelet nere to the Cundite, at the sygnee of Lucrece."

Derartige angaben ddes buchdruckers ändern sich im laufe der jahre und bieten daadurch oft eine ziemlich zuverlässige handhabe zur datierung; von drucken, welche „s. a." erschienen waren.

Wer war dieserr Berthelet? Er erscheint von c. 1528 an als buchdrucker, 15533 ward er als "Impressor Regis" bezeichnet. Er druckkte vornehmlich schönwissenschaftliches, meist übersetzungen, , so z. b. schriften von Cicero, Plutarch Frontinus, Seneca XXenophon, Terentius oder von humanisten wie Vives, Hutten, Diesiderius Erasmus, Sturmius, Guevara etc., hin und wieder auchh einen älteren englischen dichter, so z. b. Gower's Confessio Armantis (1532 und 1554). Während er auf der übersetzung vomn Guevara's Libro de Marco Aurelio, gedruckt 1559, noch alds lebend erscheint, findet sich in den 1560 
erschienen Selections from Terentius und in Senecas Thyestes Englished by J. Heywood vom gleichen jahhre die angabe: "in the house of late Thomas Berthelet". ELr ist somit 1559/60 gestorben. Auf einem 1565 gedruckten lbuche, auf Cooper's Thes. Linguae Rom. \& Brit. heifst es: "inn ædibus Berthelette per H. Wykes". Vergegenwärtigt man sich, dals die ausgabe der Mery Tales von 1567 "Impriinted at London in Fleetestreet by H. Wykes" herauskam, s60 zweifeln wir nicht, dafs H. Wykes ${ }^{1}$ ) der geschäftsnachfolger 'Berthelet's war.

Wer sich nun der mühe unterzöge,, die Berthelet'schen drucke, die im Brit. Museum in grofser anzzahl vorhanden sind (cf. den katalog), anzusehen, wird mögliccherweise durch beachtung von kleinigkeiten zur ermittlung (des genauen datums der Editio princeps gelangen.

Zum schlufs noch ein paar vermutuungen, die mit dem vorangehenden im zusammenhang stehen $\lrcorner$. Der verfasser der Mery Tales hat sich nicht genannt. Solllte es vielleicht der buchdrucker Berthelet selber gewesen ssein? Nicht unmöglich. Die buchdrucker des 16. jahrhundertts besafsen gelehrtes wissen, wenn auch nicht alle es einenm Froben gleichtun konnten. Auch von Berthelet's konkurrentten, von John Rastell, dem drucker der A Hundred Mery Talys iwird behauptet, dals er schriftstellerte. Wir kommen natürlich bei dieser verfasserfrage über die blofse vermutung niccht hinaus.

Mehr aussicht auf lösung hätte eines andere frage, aber wiederum nur durch einen besuch des Brit. Museums, nämlich die, ob der kompilator der Mery Tales nicht zum teil statt der lateinischen originale englische überrsetzungen benützte. Die Apophthegmata des Erasmus z. b. erschienen 1542 in einer übersetzung des verfassers von Raılph Royster Doyster.

1) Henry Wykes, von dem nicht viele druckke bekannt sind, drackte in der zeit von etwa 1557-1571. Auffallend ist, es, dafs er bereits 1557 ein ursprünglich bei Berthelet 1540 und 1541 lherausgekommenes buch Luis Vives' Instruction of a Christian Woman (engl. übersetzung des lateinischen originals) druckte. War das ein uneerlaubter nachdruck oder sollte schon damals H. Wykes in gewissen beziebhungen za Berthelet gestanden sein? 
Bei Berthelet kanm 1540 ein werkchen heraus, betitelt: L. Vives, An Introoduction to Wysedome translated by $R$. Morison. Sentences opf wise men gathered together by Erasmus. Vielleicht gab es nnoch von dem einen oder andern der obengenannten quellenwwerke übersetzungen. Es wäre natürlich nur durch eine sorggfältige textesvergleichung festzustellen, ob der kompilator diesse oder am ende doch nur die lateinischen originale benützt haat.

Und so liefsen : sich noch manche kleine fragen aufwerfen, meist aber von unntergeordneter bedeutung, die ich daher, wie bereits verschiiedene punkte in der einzeluntersuchung, nicht zur entscheiduung bringen will. Im grofsen und ganzen sind wir jetzt übeer die quellen der Mery Tales im klaren. Der verfasser, ein l humanistisch geschulter mann, kannte das klassische altertum I recht gut, holte sich aber seine stoffe vorzugsweise bei dden lateinischen dichtern der renaissancezeit, bei Poggio, Abstemius, Morus, Barlandus, Seb. Brant, Erasmus,, Gast usw., verschmähte es aber auch nicht, einen im verkkehr mit anderen gehörten witz zu papier zu bringen, oder eein mittelalterliches predigtmärlein in ein modernes gewand zuu kleiden.

Seiner gesinnunng nach ist er katholisch,1) und daran ändern auch die beedenklichen anekdoten nichts, die er von geistlichen erzählt; andere ernsthafte katholiken in jenen tagen verfuhren aucch nicht anders.

Obwohl von origginalität bei ihm nicht die rede sein kann, so mufs ihm doch das verdienst zuerkannt werden, dafs er gut nacherzählte, maanchmal sogar geschickt lokalisierte. Seine witze lesen sich fliielsend, zeigen eine entschieden gröIsere sprachgewandtheit aals die A C Mery Talys und sind geniefsbarer als vieles, wras gegen das ende des 16. jahrhunderts geschrieben wurde. Was seinem büchlein noch eine besondere

1) Das beweisen wendulungeu wie im 32. Tale: "Out of the towne of Parusyn were sente ... unto ouxr holye father Pope Urhan" oder im 100. Tale: "the Holy See Apostollyke", während im ersten falle in der vorlage (Poggio) "Ad Urbanum Pontificem" und im letzteren (Brant) "ad sedem apostolicam" steht. - IDer umstand würde übrigens gegen die verfasserschaft Berthelet's sprechuen, weil dieser antikatholische schriften druckte. 
bedeutung verleiht, das ist, dals es zu denn frühen proben des antiken und humanistischen einflusses in EEngland zählt.

Wie sehr das buch durch das ganzee jahrhundert fortwirkte und bis ins 17. jahrhundert beliebbt war, das ersieht man am besten aus der schamlosen weise,, wie es in späteren sammlungen, so z. b. in den 1604 gedruackten Pasquil Jests und den 1607 veröffentlichten Pleasant Connceits of Old Hobson wörtlich geplündert wurde.

\section{Nachtrag.}

Zum 121. schwank: Of the husbandrman that caused the iudge to geue sentence aggaynst him selfe. Quelle: Erasmus' Ecclesiastes sive de : ratione concionandi (Ausg. Lugd. 1543, s. 358). Man vergleichhe:

\section{Mery Tales:}

An husbandman in Zeland came before the chiefe rnler... (whose bull had kyld the poore mans cow) and after he had leaue to speake, hee sayde: my bull leapyng ouer the dyche hath kyld your cow; what is the law? The ruler, mistrusting no deceit answered: thou must paie for hir.... The ruler beyng a little amoued sayde: this is another matter. The poor man sayd: Verily it is all one thyng: and you have truely indged.

Die erzählung des Cognatus ist, zumn teil wörtlich, dem buche des Erasmus entlehnt.

MÜNCHEN.

A. L. Stiefel. 